\title{
Climate change, cryosphere and impacts in the Indian Himalayan Region
}

\author{
A. P. Dimri ${ }^{1, *}$, S. Allen ${ }^{2,3}$, C. Huggel ${ }^{2}$, S. Mal $^{4}$, J. A. Ballesteros-Cánovas ${ }^{5}$, \\ M. Rohrer ${ }^{5,6}$, A. Shukla ${ }^{7}$, P. Tiwari ${ }^{8}$, P. Maharana ${ }^{1}$, T. Bolch ${ }^{9}$, R. J. Thayyen ${ }^{10}$, \\ M. Stoffel ${ }^{5,11,12}$ and Aayushi Pandey ${ }^{1}$ \\ ${ }^{1}$ School of Environmental Sciences, Jawaharlal Nehru University, New Delhi 110 067, India \\ ${ }^{2}$ Department of Geography, University of Zurich, Switzerland \\ ${ }^{3}$ Institute for Environmental Sciences, University of Geneva, Switzerland \\ ${ }^{4}$ Department of Geography, Shaheed Bhagat Singh College, University of Delhi, Delhi 110 017, India \\ ${ }^{5}$ Institute for Environmental Sciences, University of Geneva, Switzerland \\ ${ }^{6}$ Meteodat GmbH, Zurich, Switzerland \\ ${ }^{7}$ Ministry of Earth Sciences, New Delhi 110 003, India \\ ${ }^{8}$ Department of Geography, Kumaon University, Nainital 263 001, India \\ ${ }^{9}$ School of Geography and Sustainable Development, University of St Andrews, Scotland, UK \\ ${ }^{10}$ National Institute of Hydrology, Roorkee 247 667, India \\ ${ }^{11}$ Department of Earth Sciences, University of Geneva, Switzerland \\ ${ }^{12}$ Department of F.-A. Forel for Environmental and Aquatic Sciences, University of Geneva, Switzerland
}

Climate change and related impacts over the Indian Himalayan Region (IHR) remains poorly quantified. The present study reviews observed and modelled changes in the climate, cryosphere and impacts related to hazards, agriculture and ecosystems. An increasing temperature trend over the IHR is reported, which over a few locations is found to be higher than the global average. For precipitation, a complex and inconsistent response with considerable variation in the sign and magnitude of change is observed. Future projections show significant warming. Climate-driven changes and impacts are clearly observed. Snow cover has declined since the 1960 s, with an enhanced decreasing trend during the 1990 s and variable trends since 2000 . Glaciers are losing mass and retreating at varying rates since the early 20 th century, with an exception over the Karakoram region. An observed heterogeneous response of glaciers to atmospheric warming is controlled by regional variations in topography, debris cover, circulation and precipitation. Initial assessments of permafrost extent of 1 million $\mathrm{km}^{2}$ across the IHR roughly translate into 14 times the glacier area. Extreme floods represent the most frequent natural disaster in the IHR. Studies have highlighted the significant threat from glacial lakes. Landslides occur in combination with heavy rainfall and flooding, with poor land-use practices such as road-cutting and deforestation being additional drivers. Climate change has also stressed traditional subsistence agriculture and food systems. Improving systematic and coordinated monitoring of climate and related impacts is crucial to contribute to effective climate change adaptation and response strategies.

\footnotetext{
*For correspondence. (e-mail: apdimri@hotmail.com)
}

Keywords: Climate change, cryosphere, glacier, permafrost, run-off.

\section{Introduction}

MOUNTAINS roughly cover $25 \%$ of the Earth's surface ${ }^{1}$, with about 915 million people or $12 \%$ of the global population living in mountain regions, and 90\% thereof in developing countries. Much larger number of people, however, benefit from sustenance provided by mountains to downstream regions. Associated rivers fed by snow and icemelt critically contribute to life-support systems ${ }^{2-4}$ as well as the social and economic welfare ${ }^{5}$. Mountain systems are, highly sensitive to climatic variability and change $^{6-9}$. This is especially true for the mountain cryosphere with respect to glaciers, snow and permafrost - all interacting and responding to climate in a distinct way. Recent global assessments from the Intergovernmental Panel on Climate Change (IPCC) $)^{10-12}$ have documented observed and projected impacts of climate change on the cryosphere $^{13,14}$. The recent Hindu Kush Himalayan Monitoring and Assessment Programme (HIMAP) ${ }^{15}$ report provides comprehensive information over the region. Yet mountain regions, and in particular the high mountains, suffer from the scarcity of observational data, and climate models are challenged by the complexities of mountain climate, which is strongly controlled by topography.

The Himalaya and its sub-regions prominently feature in this debate because of their importance for the vast number of people inhibiting these and the downstream regions (Figure 1). This is in contrast to the paucity of data and information available over the region. While the status and changes in the glaciers in Himalaya have been the focus of several studies in recent years ${ }^{15-17}$, some 
other groups have examined the hydrology and associated changes in the region ${ }^{18-20}$. Yet, the broader impacts of changes in climate and cryosphere on ecosystems, people and economy are either scarcely documented or quantified. The Government of India (GoI) recognized this challenge, with one of the National Missions of the National Action Plan on Climate Change (NAPCC) focusing on sustaining the Himalayan ecosystem. For the 12 States falling within the Indian Himalayan Region (IHR), State Action Plans on Climate Change have been developed for implementation. Scientific evidence on observed and projected climate, cryosphere changes and associated impacts is crucial in this context. Here we provide a review on the current state of knowledge on the IHR, focusing on climate (i.e. temperature and precipitation), and all components of the cryosphere (i.e. glaciers, snow and permafrost). In terms of impact, we concentrate on glacier lake outburst and other floods, landslides, hydrological changes and briefly on related agriculture, ecosystem and livelihood impacts. Our primary focus is the IHR, but for some cases such as for the climate, we need to extend beyond the IHR due to the importance of the context of the greater Himalayan region.

\section{Changes in climate and cryosphere over the Indian Himalaya}

\section{Present and future warming}

Warming over the Himalaya has exceeded the global average rise in temperature ${ }^{11}$ having different annual/ seasonal warming rates over its different sub-regions. Increasing temperature trends of $0.12^{\circ} \mathrm{C} / \mathrm{yr}$ (ref. 21) and $0.4^{\circ} \mathrm{C} / \mathrm{yr}$ (ref. 22) are reported over the middle Mountains and Himalaya respectively. An increase of $0.03^{\circ} \mathrm{C} / \mathrm{yr}$ from 1985 to 2002 in Bhutan in the Eastern Himalayas is also reported ${ }^{23}$. Pre-monsoon warming of $2.7^{\circ} \mathrm{C} / \mathrm{yr}$ due to aerosol interaction has been found along the Himalayan slopes ${ }^{4}$. Higher winter warming is reported over Nepal Himalaya $^{21}$, western/northwestern Himalaya ${ }^{24,25}$, upper Indus basin $(\mathrm{UIB})^{26}$ and the Tibetan Plateau ${ }^{27}$. The increasing trend in maximum temperature is higher than that of minimum temperature over the western Himalaya ${ }^{25,28}$, but increasing warm nights over western Himalaya $^{28}$ are also an indication of the rising trend in minimum temperature. A greater warming rate at higher elevation zones over Nepal Himalaya ${ }^{21}$ and greater warming with increasing altitude over India and Pakistan Himalaya $^{24}$ has been documented. While more warming over higher mountains than low elevations at the same latitude has been reported $^{29}$, more recent research has found that such elevation dependent warming (EDW) is not consistent across different mountainous regions, with the Tibetan Plateau being a region where EDW has been found $^{30}$. Regional heterogeneity of EDW is considered to be a function of various physical temperature-relevant processes such as snow albedo and surface-based feedbacks, water vapour changes and latent heat release, aerosols and others ${ }^{31}$. Generally, decreasing number of meteorological stations with increasing elevation limits better understanding in the IHR.

Future climate projections from the Coordinated Regional climate Downscaling Experiment-South Asia (CORDEX-SA) show an underestimation of mean monthly or annual temperature. However, winter warming trend over the IHR has been observed ${ }^{32}$. Increasing maximum temperature during winter reported from various models ${ }^{33}$ agrees with earlier findings ${ }^{34}$. In addition, minimum and maximum temperatures show a decreasing trend with elevation. CMIP3 and CMIP5 models studies for the period 1960-2000 suggest an increase in annual average temperature over eastern $\left(2.5^{\circ}-4^{\circ} \mathrm{C}\right)$ and western Himalaya $\left(2.8-4.5^{\circ} \mathrm{C}\right)$ by the end of 21 st century ${ }^{35}$. Over the Tibetan Plateau a projected rise of $4^{\circ} \mathrm{C}$ is estimated by 2100 compared to 1950 (ref. 25).

The projected increase in winter temperature from the present to the end of $21 \mathrm{st}$ century is reported to be $5.4^{\circ} \mathrm{C}$ under RCP $8.5^{\circ} \mathrm{C}$ over Karakoram and Northwest Himalaya $^{36}$. The increase of projected minimum temperature and warm nights over the southern Koshi basin in the Nepal Himalaya ${ }^{37}$ and UIB in the Western Himalaya, will be higher compared to the lower Indus basin (LIB) ${ }^{34}$. Various modelling studies have shown amplified warming with altitude during winter over the Tibetan Plateau ${ }^{25,30}$ and the $\mathrm{IHR}^{38-40}$ under increasing $\mathrm{CO}_{2}$ concentrations. Supplementary Figures 1-3 show average mean, minimum and maximum temperature respectively, over the IHR based on model results. These results indicate that projected climatological mean and trends of temperature are increasing, thus the climate is moving towards a warmer regime.

Based on these studies, it can be summarized that both observational and modelling studies show that there are warming trends, although with different rates, along and across the IHR.

\section{Present and future precipitation}

The Himalayan folded mountain structure leads to mountain lee wave and Bergeron's seeder-feeder mechanisms ${ }^{41,42}$. Moist orographic interactions modulate precipitation distribution over the IHR ${ }^{43-45}$. Orographic interactions block and force moisture upwards resulting in strong vertical, horizontal and slope-wise precipitation gradients ${ }^{42,46-48}$. Windward sides receive higher precipitation than leeward $\operatorname{sides}^{49}$. The uneven distribution of rainfall in the mountains results in differential rainfall trends within small distances, and leads to floods and droughts ${ }^{45}$. Eastern and Central Himalaya receive $80 \%$ of the annual precipitation due to the Indian summer monsoon (ISM), whereas the western Himalaya receives $\sim 30 \%$ due to western disturbances (WDs) ${ }^{16,50}$ which, however, are embedded in the 


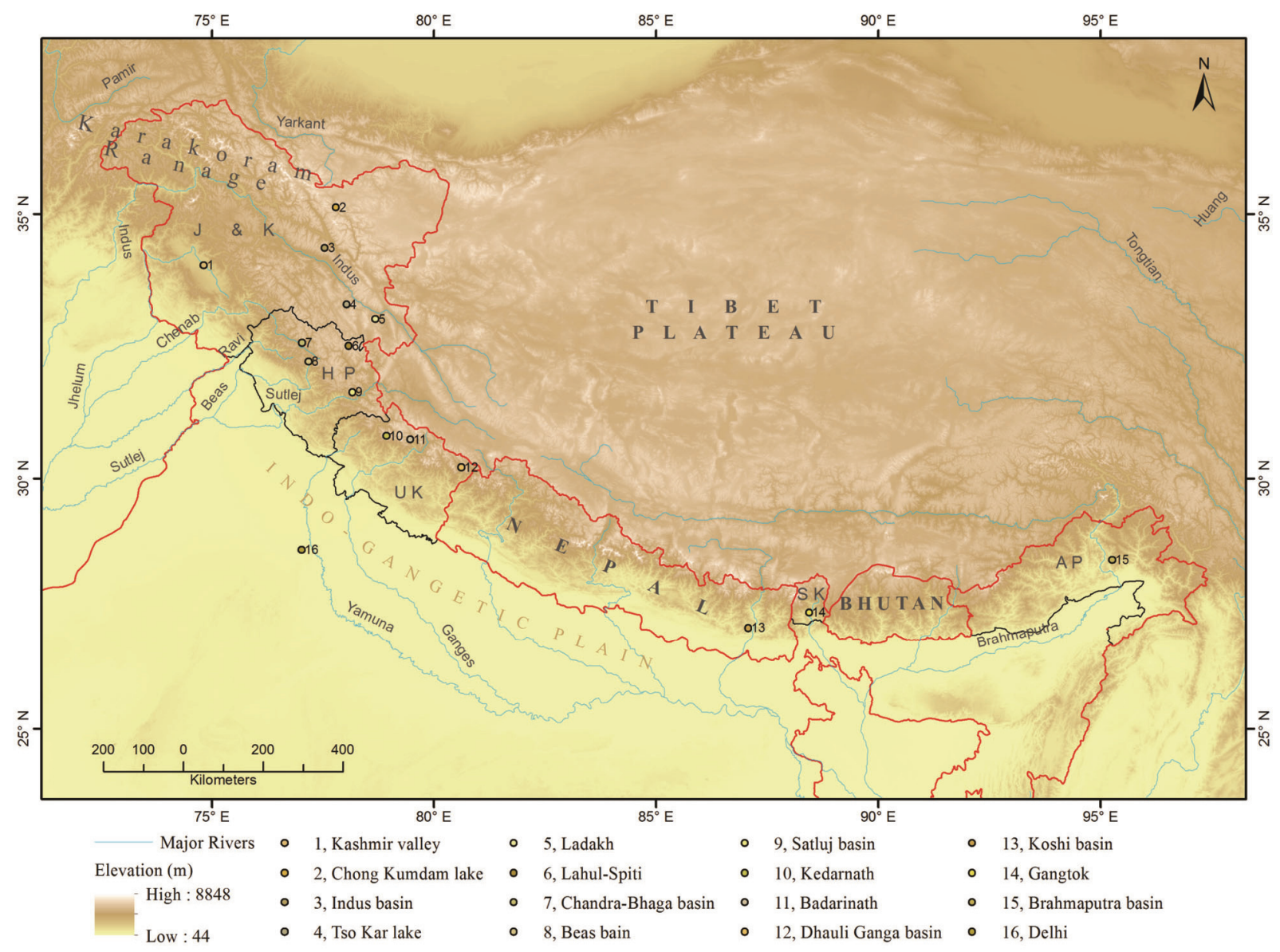

Figure 1. Location of study area with important places referred to the paper. The red line indicates the international boundary of India, while the grey lines indicate the boundaries of Himalayan states in India. J\&K, Jammu and Kashmir; HP, Himachal Pradesh; UK, Uttarakhand; AP, Arunachal Pradesh. State of J\&K and HP belongs to western Himalaya; UK and Nepal to central Himalaya and SK, Bhutan and AP to eastern Himalaya. Various locations are as well marked for better understanding of the region. The background elevation (ASTER GDEMV2) is obtained from earthexplorer.usgs.gov.

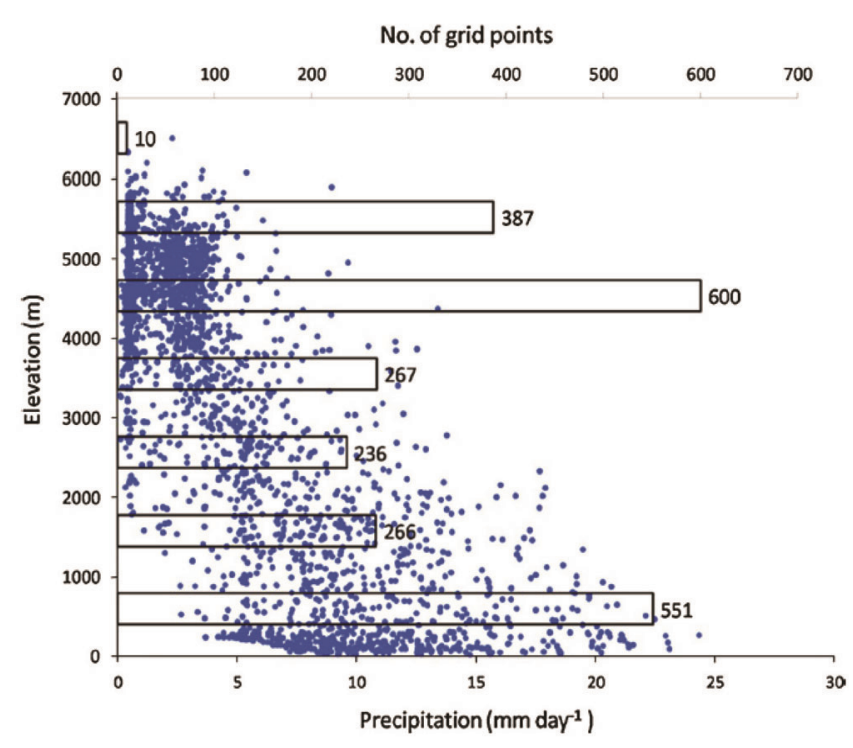

Figure 2. Variation in observed monsoonal precipitation with elevation. The bars show the number of grid points at each $1000 \mathrm{~m}$ elevation bins ${ }^{67}$.
Indian winter monsoon (IWM) $)^{34,44,51}$. The precipitation relevant east-west divide is around the Sutlej valley in the western Himalayas. Catchments towards the east (west) get 70\% (50\%) annual precipitation due to $\mathrm{ISM}^{49}$. Figure 2 shows a modelled elevation-dependent precipitation distributions. It clearly shows that higher elevations receive precipitation within a smaller range and vice versa.

The increase of extreme rainfall events leading to floods seems to be heterogeneous across India, showing a slight decrease in the central and northern parts of the country, and an increase of extreme events in the east and North East of India ${ }^{52}$. An increase of cloudburst events has been furthermore recorded in the Central Himalaya ${ }^{53}$, although limitations associated with the length of observations have to be considered. Increases in extreme rainfall events during the last decades have been associated with an increase in sea surface temperature over the tropical Indian Ocean ${ }^{54}$.

Observational studies show no clear seasonal and annual precipitation trends over the IHR, but regionally some changes are observed. For instance, increased 


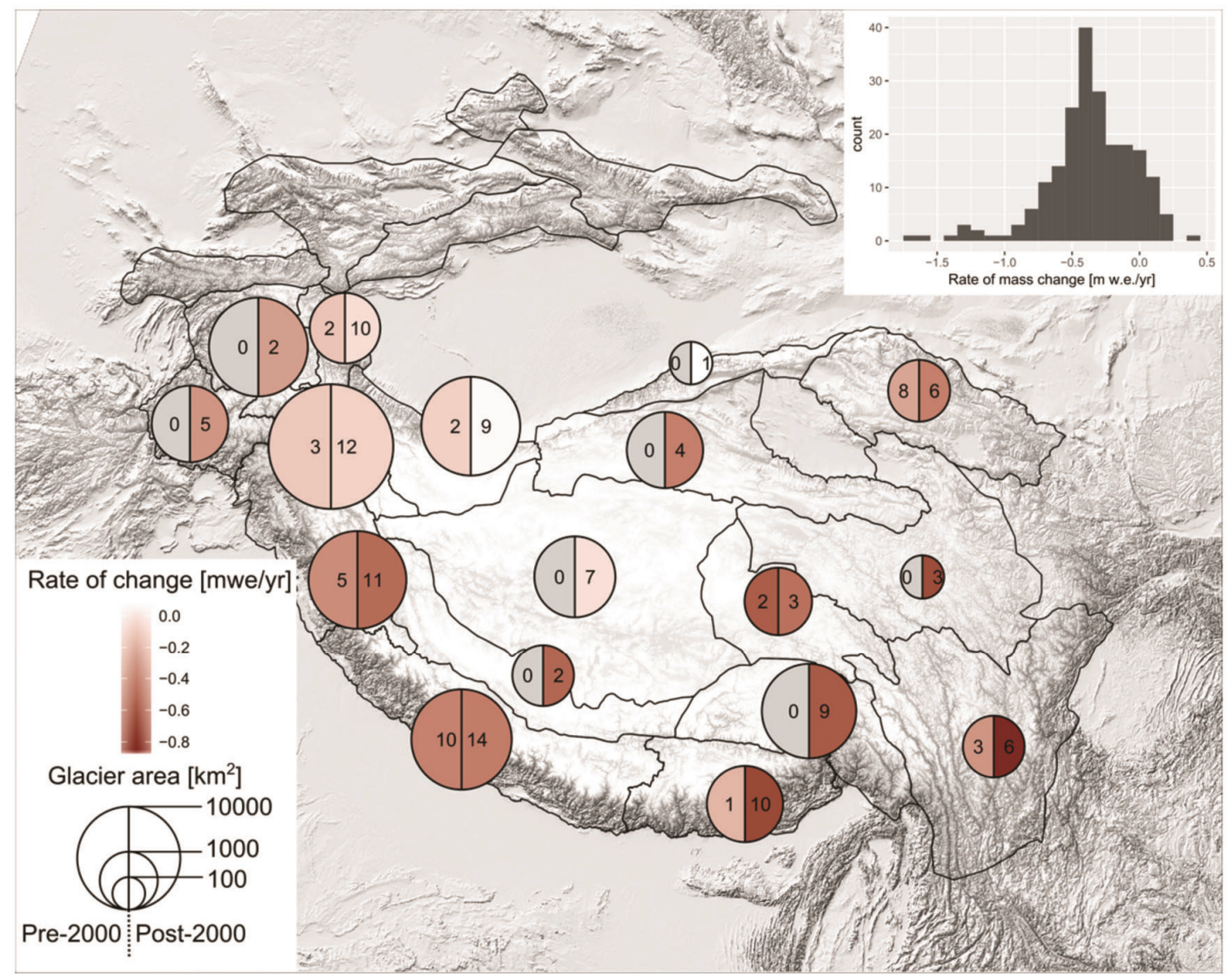

Figure 3. Summary of 164 glaciological, geodetic, and modelling estimates of rates of glacier mass change (m w.e./yr) by glacier region. The arithmetic average of data from all studies pre and post-2000 is shown by the shading of half circles (pre-2000 left, post-2000 right), together with the number of studies available for each period; periods without data are coloured in grey. A histogram of all reported regional mass change rates is given in the upper right (Source: Bolch et al. ${ }^{219}$ ).

average precipitation and significantly decreased light precipitation events are reported for the Hindu-Kush Himalaya $(\mathrm{HKH})$ and the central Indian region ${ }^{55}$, while increased winter precipitation is noted for the Karakoram ${ }^{35}$. Increased precipitating $\mathrm{WDs}^{56}$; increasing (decreasing) seasonal winter (summer) precipitation and mild increase in annual precipitation have been found over the Beas basin in Himachal Pradesh ${ }^{57}$, and the Koshi basin in the Nepal Himalaya ${ }^{46,47}$, whereas decreasing monsoonal precipitation has been observed over the Uttarakhand region, Central Himalaya ${ }^{45,58}$. For the Eastern Himalaya annual precipitation is declining, but precipitation has increased during the later phase of the monsoon period ${ }^{58,59}$.

Changes in precipitation extremes are challenging to detect in sparsely equipped mountain areas, but have been found for a number of regions: over the western Himalaya increasing extreme precipitation up to $3000 \mathrm{~m}$ and decreasing at higher elevations can be observed ${ }^{60}$. Also, decreased monsoon precipitation over the Hindu-Kush and the western Himalaya, and increasing extreme precipitation over the Karakoram, the western Himalaya and UIB have been reported ${ }^{55,61-63}$, with a periodicity of 2.7 years in extremes ${ }^{59}$.
Regional climate models (RCMs) are not capable of accurately resolving the precipitation distribution over the $\mathrm{IHR}^{41,64}$, being sensitive to horizontal resolution, variable topography and heterogeneous land use $\mathrm{s}^{43,44}$, local atmospheric circulation $^{44}$ and extremes ${ }^{65}$. Improved parameterization is able to reproduce extreme wet and dry years $^{44,64}$, and precipitation (snow cover) over the foothills (central Himalayas), but underestimates snow cover over the eastern Himalaya ${ }^{66}$. A wet bias over the western Himalaya $^{64}$ and elevation dependency of summer precipitation can be observed ${ }^{67}$. Projected increased monsoonal precipitation $^{68,70-72}$, with increased extreme events ${ }^{35,63,69}$ and decreased number of rainy days ${ }^{69}$, is predicted for the end of the 21 st century. Increased converging moisture from the Arabian Sea leading to increased ISM precipitation over western Himalaya is projected $^{68,69}$ whereas a few researchers reported no specific precipitation trends ${ }^{63}$. Global climate model (GCM) based projections show increased summer (23-35\%) and winter (17-28\%) precipitation along with precipitation extremes over eastern Himalaya. RCMs depict decreased (increased) projected summer rainfall over the Central (eastern and western) Himalaya ${ }^{35,68,73}$. A model-based distribution of 
monsoonal precipitation averaged over the IHR is shown in Supplementary Figure 4.

Based on the above discussion of precipitation distribution and variability, higher elevation regions have a higher drying rate than the lower elevation regions. This is primarily due to orographic forcing in association with increased surface warming. However, in the IHR, the coupling between moisture and temperature is complex and the primary precipitation mechanisms (and thus associated precipitation) are not simple to characterize.

\section{Glacier change}

Estimates of glacier coverage in the IHR vary from $\sim 30,000 \mathrm{~km}^{2}$ (ref. 74), $\sim 25,000 \mathrm{~km}^{2}$ (ref. 75) to $\sim 14,000 \mathrm{~km}^{2}$ based on the most recent version of the Randolph Glacier Inventory ${ }^{76}$. These differences could be attributed to the fact that different datasets and varying methodologies were employed, and monitoring was done over sub-regions with disputed boundaries. Many glaciers in the Himalaya are heavily debris-covered at their tongues. Debris coverage varies between $\sim 5 \%$ and $\sim 15 \%$ of the glacier area in different regions of the Himalaya ${ }^{77}$. Thick debris cover significantly reduces ice melt and many debris-covered glacier tongues are relatively stable ${ }^{78,79}$. However, these glaciers are also significantly losing mass ${ }^{80,81}$. Compilations pertaining to temporal variations suggest that glaciers in the Himalaya have on the average been degenerating at varying rates since the 19th century, with an exception of the Karakoram glaciers which have shown long-term irregular behaviour $^{16,17,75,82-84}$.

Regional estimates of glacier length changes suggest that the western Himalayan glaciers (Jammu and Kashmir, Himachal Pradesh) experienced enhanced retreat compared to those in the Central (Uttarakhand) and eastern Himalaya (Sikkim) ${ }^{46,79,85}$. However, results of snout monitoring might be biased towards larger glaciers as area change estimates show similar or even higher loss rates in Sikkim compared to Himachal Pradesh ${ }^{86-88}$. Glaciers in the Central (Garhwal) Himalaya show average shrinkage rates ${ }^{87-89}$, while small glaciers in the eastern parts of Jammu and Kashmir (Ladakh) experience relatively little recession ${ }^{90}$. Kraaijenbrink et al. ${ }^{91}$ have shown that a global temperature rise of $1.5^{\circ} \mathrm{C}$ will lead to a warming of $2.1^{\circ} \pm 0.1^{\circ} \mathrm{C}$ in High Mountain Asia (HMA), and that about $64 \pm 7 \%$ of the present-day ice mass stored in the HMA glaciers will remain by the end of the century.

Glaciers in the Karakoram have shown individually contrasting behaviour, but on average stable areas ${ }^{92,93}$, and balanced mass budgets since the $1970 \mathrm{~s}^{94-96}$. Many glaciers in the northwestern IHR are of surge type; hence they periodically speed up and advance rapidly ${ }^{83,92,97,98}$. Surface velocity measurements also reveal that glaciers in the Karakoram region are almost active at their snouts. The concentration of stagnant glaciers is highest in the Central and eastern Himalaya and can be related to local topography and the presence of debris cover ${ }^{79,99,100}$. In contrast to the Karakoram, clear mass loss was found for almost all other Himalayan ranges. In situ measurements indicate moderate mass loss until the $\sim$ mid 1990s and an increased mass loss thereafter ${ }^{16}$. However, glaciers in northern Himachal Pradesh (Lahaul-Spiti) might have experienced a period of only slight mass loss during the 1990s (ref. 101). The highest loss rates after $\sim 2000$ are seen in the western Himalaya $\left(>-0.6 \mathrm{~m}\right.$ w.e. $\left.\mathrm{a}^{-1}\right)$ followed by the eastern Himalaya including the ranges of Arunachal Pradesh ( 0.5 to $-0.6 \mathrm{~m}$ w.e. $\left.\mathrm{a}^{-1}\right)$, and the least mass loss was found in the central Himalaya (Garhwal in Uttarakhand) $\left(\sim 0.4 \mathrm{~m} \text { w.e. } \mathrm{a}^{-1}\right)^{17,102}$. However, large variability also exists in glacier mass balances. The observed heterogeneity in the response of glaciers to climate change may be attributed to differences in topography, debris cover and meteorological mechanisms which are regionally unique ${ }^{47,79,103-105}$.

Widespread deglaciation in several regions has led to glacier fragmentation, vanishing of smaller glaciers, formation and enlargement of glacial lakes and increase in supraglacial debris cover ${ }^{16}$. Figure 3 shows the distribution of modelling estimates of rates of glacier mass change.

\section{Snowcover change}

Snow, being one of the most sensitive natural resources, warrants comprehensive temporal assessment of various metrics at different scales. At global scale due to its highly reflective nature, snow greatly impacts climate variations, surface hydrology and energy exchange ${ }^{5,106}$. At the basin scale, seasonal snow cover acts as an important shortterm freshwater storage and key input to glacier mass balance, volumetric meltwater run-off modelling and snow hazard prediction studies ${ }^{10,19,107-114}$. Despite its distinct water storage characteristics and immense societal as well as climatic significance, research on snow cover dynamics in the IHR has lagged behind, with limited regional $^{115-117}$, and even fewer basin-scale studies ${ }^{118-120}$.

Data on snow-cover changes over the IHR are scarce. Studies that have examined various mechanisms and processes using satellite-derived snow-cover estimates over the IHR have emphasized the temporal variability of snow cover ${ }^{121-124}$. Studies reporting pre-2000 snow-cover changes in the IHR, though rare, in general point towards a decline after the 1960s which accentuated towards the decade of the 1990s and was also synchronous with an increase in snow melt ${ }^{115,124,125}$ (Figure 4). Post-2000, several studies have reported varying rates of snow cover depletion for different regions of the IHR (Figure 4). Using the MODIS eight-day-snow cover product, Gurung et $a l .{ }^{116}$ reported an increasing snow-cover trend of $10-12 \%$ 
in the eastern and western Himalaya, and a declining trend of $12-14 \%$ for the Central region of HKH between 2000 and 2010. For almost the same time period (2000 2011) but at a basin-scale, an increasing snow-cover trend has been found for the Indus basin while decreasing trends have been reported for the Ganga and Brahmaputra basins ${ }^{117}$. Contrasting results have also been reported by Rathore et al. ${ }^{120}$ for the three sub-basins of Ganga river, where they found a statistically insignificant increase of approximately $1-2 \%$ in snow cover in the Central Himalaya (Uttarakhand region). Contrary to Singh et al. ${ }^{117}$, but in agreement with Gurung et al. ${ }^{116}$, the study by Mukhopadhyay ${ }^{119}$ shows that snow cover in the Brahmaputra basin increased by $\sim 32 \%$ from 1980 to 2010 and remained stable from 2000 to 2010 (Figure 4). This is attributed to the recent increase in the amount of moisture supplied by moist air mass that incurs into the Brahmaputra valley.

A number of snow-cover monitoring studies have been carried out in the western Himalayan region at the basin scale for varying time-periods ranging between 1988 and 2012 (refs 118, 126-129). Studies spanning the extended western Himalayan regions (including Karakoram) report overall increasing or stable snow cover trends since 2000 (refs 128, 129) except for a decreasing winter snow-cover trend for the $\mathrm{UIB}^{118}$. However, studies specifically from the IHR reveal a secular decline in snow-covered $\operatorname{areas}^{126,127}$ (Figure 4).

\section{Permafrost}

Permafrost is sediment or bedrock that remains frozen for at least two consecutive years. It mainly occurs in the Arctic $^{130}$ and high mountain areas ${ }^{131-133}$. It encompasses around $25 \%$ of the land mass of the Northern Hemisphere ${ }^{134}$. A number of studies have shown that permafrost has thawed in the Northern Hemisphere during the past couple of decades ${ }^{135-138}$. However, permafrost studies are sparse in the HKH region in general and the IHR in particular $^{139}$. In the IHR, cryospheric studies are largely

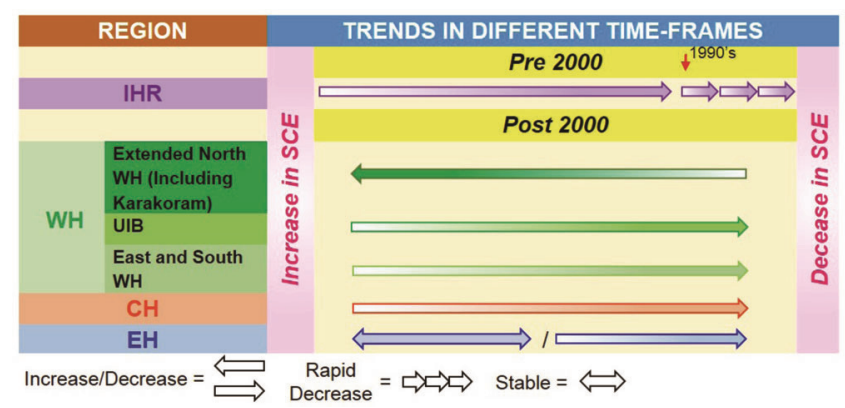

Figure 4. Snow cover trends over the Indian Himalayan region (IHR) in different time frames. Pre-2000 snow cover studies are rare, however, report a generalized decline in snow cover. Post-2000 studies reveal variable snow cover dynamics in different Himalayan regions. WH, western Himalaya; UIB, Upper Indus Basin; $\mathrm{CH}$, central Himalaya; EH, eastern Himalaya; SCE, Snow Cover Extent. focused on snow and glaciers due to their visible impacts on the environment and resources. More recently, with increasing human stressors and a changing climate, research has begun to focus on the finer details of water resource dynamics in the IHR, to include first studies on subsurface permafrost. Of late, research on permafrost is being initiated by national and international agencies in the IHR. Conclusive evidence of permafrost in the IHR was first gathered from Tso Kar lake area (cold-arid regions of Jammu and Kashmir) in 1975-76 from a study conducted by the Geological Survey of India (GSI) ${ }^{140}$. Boreholes drilled up to $29 \mathrm{~m}$ depth had many ice layers interspersed with sandy gravel layers, and annual average temperature of $-2^{\circ} \mathrm{C}$ indicated permafrost area across $\sim 20 \mathrm{~km}^{2}$. An initial modelling assessment on a regional scale suggests that the permafrost area in the HKH region could extend up to 1 million $\mathrm{km}^{2}$, which roughly translates into 14 times the area covered by glaciers ${ }^{139}$. Studies on rock glacier distribution (a surface landform indicative of permafrost) have also been carried out in the recent past, suggesting that the lower limit of permafrost in the region lies within $3500-5500 \mathrm{~m}$ asl (refs 141). Allen et $a l{ }^{142}$ suggested a permafrost spread of $420 \mathrm{~km}^{2}$ in Kullu district, located in north-central parts of Himachal Pradesh. The cold-arid region of the eastern parts of Jammu and Kashmir has reported sporadic occurrence of permafrost and associated landforms ${ }^{139}$ with sorted patterned ground and other periglacial landforms such as ice-cored moraines. Catchment-scale studies suggest that the ground ice melt component may be a critical water source during dry years in the cold-arid regions of Jammu and Kashmir $^{143}$. This region has large areas of high-altitude wetlands and lakes, and the studies indicated phases of permafrost growth during low lake levels, especially since $5 \mathrm{kyr}$ BP. Continuous development of permafrost mounds and thermokarst features is also inferred during the last 60 years ${ }^{144}$. These studies have firmly established significant permafrost coverage in high mountain areas of the IHR. As glaciers and snow cover are shrinking across most parts of the IHR, in response to changing climate, permafrost areas are also expected to respond in a comparable manner as evident from other similar cryospheric areas globally. Using modelling strategies, Schaphoff et $a l .{ }^{145}$ have shown that vegetation responds more rapidly to warming of the permafrost zone than soil carbon pools due to long time lags in permafrost thawing. Possible permafrost thaw-related impacts have been inferred from other areas which include changing frequency and spatial distribution of landslides, changes to vegetation and runoff patterns, changes in water quality and sediment load in rivers, with important implications for populations dependent on these high-altitude ecosystems ${ }^{139}$. However, long-term monitoring and evidence of such impacts in the IHR are generally lacking. For example, landslides are widespread across the IHR, but interestingly, large high mountain slope failures are rarely documented, and as yet 
there is no evidence to suggest that thawing of permafrost has any notable influence on mass movement activity in the IHR.

Given that permafrost covers an area 14 times larger than that covered by glaciers, the potential effects of permafrost melting in the IHR need further studies to better understand both immediate and long-term consequences.

\section{Upstream and downstream impacts}

\section{Glacier lake outburst floods}

Glacial lakes are a common feature in high mountain regions and are closely associated with regional patterns of glacial response to climate change ${ }^{111,146}$. A first comprehensive inventory of glacial lakes led by ICIMOD (with support of various institutions) revealed around 8790 glacial lakes (1999-2003) across the broader HKH region, from which 1900 were located in the IHR (ref. 147 and references cited therein). In their studies in the IHR, Worni et al. ${ }^{148}$ and Fujita et al. ${ }^{149}$ identified 251 and 500 glacial lakes respectively $\left(>0.01 \mathrm{~km}^{2}\right.$ area). This discrepancy in the results can be attributed to the different thresholds (minimum lake size) and methods (manual or semi-automated lake detection) adopted for the mapping of glacial lakes ${ }^{150}$; Table 1 and Supplementary Table 1. Furthermore, these discrepancies highlight the difficulties in directly comparing different inventories in the region, leading to uncertainties in the baseline data that feed into related adaptation planning and risk reduction strategies.

Across the IHR, the number and area of glacial lakes have rapidly increased as a result of a warmer climate during the last century ${ }^{146,147,151,152}$. According to Nie et $a l .{ }^{150}$, the number and area of glacial lakes in the IHR on an average has increased by about $8.8 \%$ and $14 \%$ respectively, during 1990-2015. Glacial lakes connected or located close (less than $2 \mathrm{~km}$ ) to the glaciers particularly showed enhanced expansion (about 50\%) ${ }^{151,153}$, and contributed most (about 83\%) to total growth of glacial lakes during $1990-2015$ in the region ${ }^{150,151}$. Furthermore, higher growth of glacial lakes is observed on southern slopes of the Himalaya compared to the northern slopes. Longitudinally, highest growth has been observed in central Himalaya, followed by eastern Himalaya, while expansion has been slowest in the western Himalaya ${ }^{146,150}$. The emergence and expansion of new glacial lakes have been mostly concentrated at higher elevations (4800-5700 m), and observed even at $5900 \mathrm{~m}$, indicating enhanced warming at higher elevations ${ }^{150}$. Local assessment studies in the IHR, e.g. Himachal Pradesh ${ }^{154}$, Chandra basin, Himachal Pradesh ${ }^{155,156}$, Chandra-Bhaga basin, Himachal Pradesh $^{157,158}$, Uttarakhand ${ }^{159}$; Alaknanda basin, Uttarakhand ${ }^{160}$; Dhauli Ganga basin, Uttarakhand ${ }^{161}$; Sikkim Himalaya ${ }^{162-164}$ confirm the emergence and rapid expansion of glacial lakes across the entire region. While lakes that are no longer fed by glacier melt have remained nearly unchanged in the region ${ }^{150,151,153}$, such lakes can still pose a substantial threat to downstream communities ${ }^{159}$. For example, disconnected lakes at the side of a glacier (icemarginal lakes) can become unstable where adjacent glaciers are losing mass and thereby removing support from the dam ${ }^{159,165}$. The increasing potential of large ice and rock mass failures into lakes, leading to glacier lake outburst floods (GLOFs), has been demonstrated in the IHR by Allen et al. ${ }^{165}$, and hence, an increasing trend in GLOF potential is expected over the 21 st century.

In the larger HKH region, the frequency of GLOFs is reported by some authors to have increased around the mid-20th century ${ }^{152,166,167}$. However, in the IHR, GLOFs have been rarely reported ${ }^{168}$, except for the Chong Kumdam GLOFs $(1929,1932,1933$ and 1939) in the $\mathrm{UIB}^{169,170}$ and the devastating Chorabari GLOF (2013) above Kedarnath in Uttarakhand ${ }^{165,171-173}$. Coxon et al. ${ }^{172}$ and Sangode et al. ${ }^{173}$ described evidence of palaeoGLOFs based on studies of sediment deposits in parts of western Himalaya (Lahaul and Ladakh). Although no GLOF events have been recorded in the eastern Himalaya (Sikkim), field evidence and local knowledge support their past occurrences ${ }^{164}$. The relative lack of GLOF evidence may be explained by the fact that the overall area of glacial lakes and their expansion is comparatively lower in the IHR than other Himalayan regions, e.g. Nepal, Tibet and Bhutan ${ }^{146,150}$. However, there may also be issues of under-recording, with some past GLOF events being recorded as flash-flood events. Several studies provide assessments of current potential GLOF hazards across the IHR, and there is general consensus that the greatest density of critically dangerous lakes occur in Sikkim (Figure 5 and Table 1).

Ives et al. ${ }^{147}$ reported 70 potentially dangerous lakes in the IHR. By comparison, Worni et al. ${ }^{148}$ identified 12 critical lakes in the IHR. Local assessment studies reveal even more diverse results as an outcome of differences in the adopted methods (Figure 5 and Table 1). These differences across the studies highlight the need for comprehensive and homogeneous large-scale assessment studies to be undertaken in the IHR. It is important to mention that no earlier assessment studies have identified critical lakes in Uttarakhand (Figure 5 and Table 1). Thus, the processes relating to the Chorabari GLOF above Kedarnath (2013) was clearly not well captured in these previous assessments. Retrospectively, Allen et al. ${ }^{174}$ analysed the hydrological and topographic characteristics of Chorabari lake, suggesting that such lakes fed entirely from rainfall and snowmelt (without connectivity to glacio-hydrological system), may be most susceptible to breaching during heavy snowmelt and rainfall events ${ }^{159}$. Furthermore, these GLOFs events may become increasingly more important in future, as glacial systems transform into paraglacial systems dominated by fluvial drainage $^{159}$.

CURRENT SCIENCE, VOL. 120, NO. 5, 10 MARCH 2021 
NATIONAL MISSION ON HIMALAYAN STUDIES

Table 1. Status of glacial lakes in different states and selected sub-basins in IHR

\begin{tabular}{|c|c|c|c|}
\hline Area & Number of glacial lakes & Hazard assessment & References \\
\hline \multirow[t]{2}{*}{ Jammu and Kashmir (Indus Basin) } & $1400\left(>0.01 \mathrm{~km}^{2}\right)$ & 40 Lakes potentially dangerous & 147,220 \\
\hline & $103\left(>0.01 \mathrm{~km}^{2}\right)$ & 2 Lakes critical & 148 \\
\hline \multirow[t]{3}{*}{ Uttarakhand } & $127\left(>0.01 \mathrm{~km}^{2}\right)$ & 0 Lakes potentially dangerous & 147,221 \\
\hline & 362 & 8 Lakes potentially critical & 159 \\
\hline & $27\left(>0.01 \mathrm{~km}^{2}\right)$ & 0 Lakes critical & 148 \\
\hline Dhauli Ganga basin (Kali Ganga) & 7 & 2 Lakes potentially hazardous & 161 \\
\hline Alaknanda basin & $45\left(>0.01 \mathrm{~km}^{2}\right)$ & 0 Lake vulnerable and susceptible to outburst & 160 \\
\hline \multirow[t]{3}{*}{ Himachal Pradesh } & $156\left(>0.01 \mathrm{~km}^{2}\right)$ & 16 Lakes potentially dangerous & 147,222 \\
\hline & $65\left(>0.02 \mathrm{~km}^{2}\right)$ & 23 Lakes potentially dangerous & 154 \\
\hline & $45\left(>0.01 \mathrm{~km}^{2}\right)$ & 2 Lakes critical & 148 \\
\hline Satluj Basin, Himachal Pradesh & $40\left(>0.01 \mathrm{~km}^{2}\right)$ & 3 Lakes potentially dangerous & 147,222 \\
\hline \multirow[t]{2}{*}{ Chandra-Bhaga Basin } & 31 & 2 Lakes potentially dangerous & 157 \\
\hline & $26\left(>0.005 \mathrm{~km}^{2}\right)$ & 16 Lakes susceptible to outburst & 158 \\
\hline \multirow[t]{5}{*}{ Sikkim } & $266\left(>0.01 \mathrm{~km}^{2}\right)$ & 14 Lakes potentially dangerous & 147,223 \\
\hline & $50\left(>0.01 \mathrm{~km}^{2}\right)$ & 8 Lakes potentially dangerous & 148 \\
\hline & $472\left(>0.01 \mathrm{~km}^{2}\right)$ & 16 Lakes high - medium susceptibility & 164 \\
\hline & $37\left(>0.1 \mathrm{~km}^{2}\right)$ & 18 Lakes potentially dangerous & 163 \\
\hline & - & 12 Potentially dangerous & 162 \\
\hline
\end{tabular}

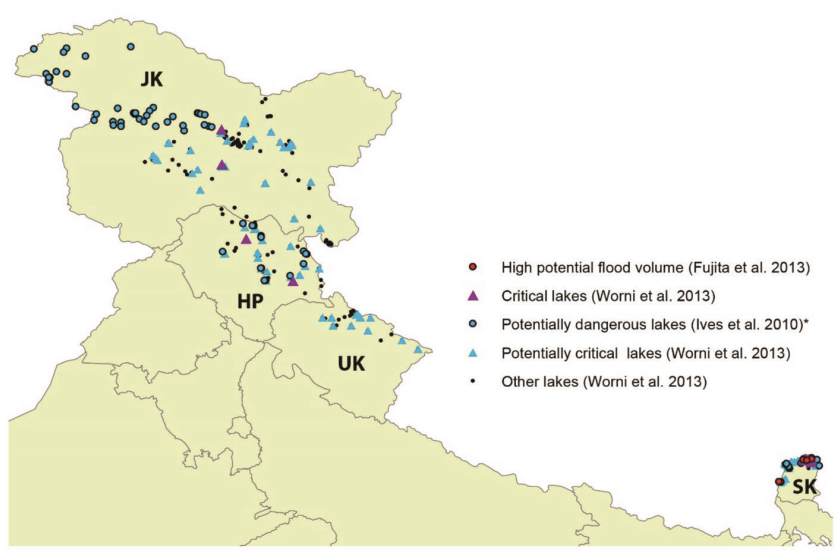

Figure 5. Comparison of GLOF hazard assessment results conducted across the Indian Himalayan Region (IHR). $(*)^{147}$ is based on underlying inventories compiled for Himachal Pradesh: HP ${ }^{220}$, Uttarakhand: $\mathrm{UK}^{221}$, Sikkim: $\mathrm{SK}^{222}$, and Indus basin of Jammu and Kashmir - JK ${ }^{219}$. No critical, potentially dangerous or potentially critical lakes have been identified in Arunachal Pradesh.

Given the close proximity of development activities (including roads, dams, hydropower, and tourism infrastructure) to glaciated mountain headwaters across the IHR, a coordinated regional analysis of glacial lake development and associated GLOF risk is urgently required.

\section{Floods and landslides}

Floods and landslides are common across the $\mathrm{IHR}^{175}$, and are characterized by extraordinary capacity for fluvial erosion and sediment transport ${ }^{176}$. Triggering processes include intense rainfall associated with the lift of humid monsoon air masses along the Himalayan relief ${ }^{177}$, cloudburst $^{39}$, and/or snowmelt processes ${ }^{178,179}$. Every year, flood and landslide disasters cause substantial economic losses and death in populated downstream valleys. Extreme events disrupt infrastructure and can enhance poverty levels within local vulnerable communities ${ }^{180}$. Massive floods can also trigger the outbreak of epidemics $^{181,182}$, and stress crops or ecosystems ${ }^{183}$. Landslides can block river corridors, creating ephemeral lakes with a risk of dam failure causing devastating downstream flooding ${ }^{184,185}$, and provide large amounts of sediment which affects fluvial geomorphology ${ }^{176}$.

Recent disasters in the IHR have highlighted the vulnerability of the population living in the region (Figure 6), most notably with the catastrophic June 2013 events in Uttarakhand $^{174}$, and during September 2014 and March 2015 in Jammu and Kashmir ${ }^{186}$. According to Singh and $\operatorname{Kumar}^{180}$, more than 88,000 lives have been lost in India since the 1950s due to floods alone, with an average economical cost of almost US\$ 460 million/yr. Main contributing factors increasing the risk from extreme events include the intensified human use of exposed mountain catchments and downstream flood plains, poor land-use practices such as deforestation and road construction, as well as issues of illiteracy, gender and other social characteristics of the population living in rural zones $^{187-191}$.

Positive trends in flood occurrences have been reported over India during the last few decades ${ }^{180,192}$. Kumar and Santosh found positive, but not statistically significant trends in flood peaks during the last five decades in Himachal Pradesh. This observation agrees with the reconstructed regional tree-ring flood records from the north-central parts of Himachal Pradesh ${ }^{193}$, and the increasing trends observed over the northwestern IHR during the last three decades ${ }^{194}$. Long-term palaeoflood and historical records can provide a stronger basis from which to assess extreme events and associated trends over recent decades. Based on such records ${ }^{195}$, it has been concluded 
that the frequency of high-magnitude floods has increased significantly during the last decades of the 20th century across India, while Ely et al. ${ }^{196}$ reached similar conclusions for the central part of India. In the Kashmir valley, the magnitude of recent floods events (including the devastating events of 2014) is comparable to the extreme events that took place during the last centuries ${ }^{197}$. Multicentenial palaeoflood records in the central Indian Himalaya indicate an increase in flood frequency during the last two centuries ${ }^{198}$, and show the key role of landslide lake outburst floods (LLOFs). Kale et al ${ }^{195,199}$ suggested an analogy between the cluster of large flood events in the recent decades and those identified during the medieval warming period. Overall, while there is some consistency in increasing flood occurrences over the past decades across the IHR, underlying trends in extreme rainfall events are heterogeneous, thus suggesting that other factors such as land-use change likely play a role.

\section{Hydrology, agriculture and ecosystems}

The extent to which changes in climate and the highmountain cryosphere have and will translate into impacts on run-off and hydrology varies significantly across different basins of the IHR, owing to the contrasting influences of monsoon, snow, and glacier regimes ${ }^{200}$. Whereas earlier assessment reports of the IPCC have generalized the role of the Himalayan cryosphere as sustaining runoff during the summer melt season (as is valid for many other alpine regions of the world); a more complex picture is now evident. The present-day contribution of snow and ice meltwater is considered important to river run-off in the Indus and Brahmaputra basin ${ }^{19}$, with overall relative annual melt contributions of up to $46 \%$ and $19 \%$ respectively ${ }^{201}$. However, in the monsoon-dominated

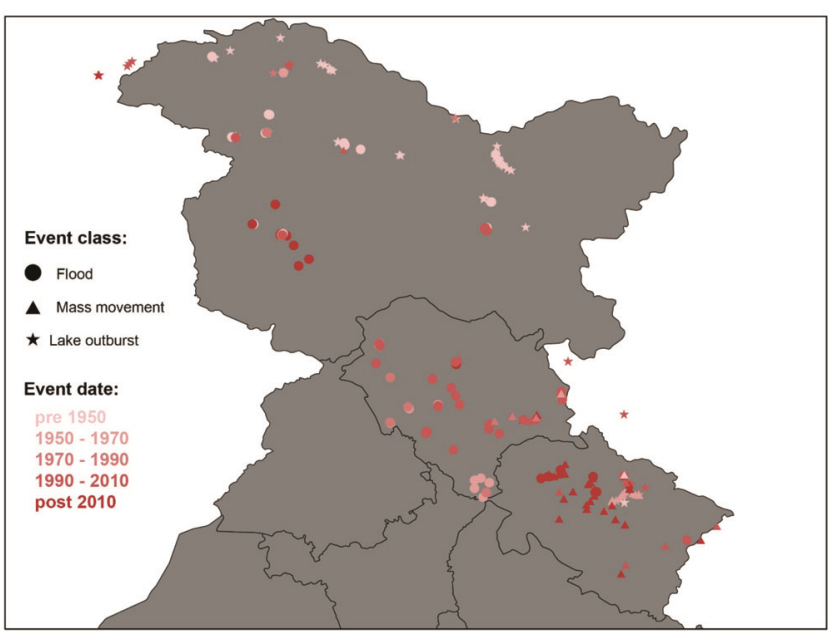

Figure 6. Overview of major flood, lake outburst (GLOFs and LLOFs) and mass movements across Jammu and Kashmir, Himachal Pradesh and Uttarakhand. Event locations are based on a review of published literature.
Ganges basin, the contribution is more modest at only $9 \%$. Here, meltwater typically only supplements the peak summer flow generated by the monsoon rainfall, although glaciers play an important buffering role during low monsoon years ${ }^{200}$. Under projected future changes in climate, a general increase in runoff is consistently demonstrated across all basins until around the mid-21st century, owing to changes in precipitation and/or accelerated melt ${ }^{19,20}$. However, as glacier area decreases, late spring and summer discharges will eventually reduce considerably, particularly for the Indus and Brahmaputra basins, with potentially severe consequences for food security ${ }^{19}$.

One of the largest sources of uncertainty in understanding past and future changes in run-off relates to the paucity of in situ measurements of snow cover ${ }^{202}$. This is crucial, because even where snowmelt contributes only modestly to annual run-off totals, as in the case of the Ganges, the contribution may be significant during the spring months ${ }^{203}$. It is therefore evident that climatic changes - in the form of increasing temperature or decreasing winter precipitation-might have important and as yet poorly quantified impacts on the timing or amount of spring snowmelt, with related implications for sustaining agriculture when other sources of run-off are scarce.

Additional to the impacts of changing cryosphererelated run-off on agriculture, the Himalayan agroecosystems have been stressed through higher mean annual temperatures, altered precipitation patterns and frequent extreme weather events ${ }^{12,21,204}$. However, a variety of changes have emerged in traditional resource utilization patterns mainly in response to population growth and rapid urbanization in the region ${ }^{205,206}$. These changes have sharply accentuated pressures on food and livelihood systems through disruption of ecosystem services and collapsing of conventional production systems, where subsistence agriculture in the Himalayan region often constitutes a main source of rural food and liveli$\operatorname{hood}^{207,208}$

For example, $\mathrm{Xu}$ et $a .^{209}$ discuss that changes in climate and melting of the Himalayan glaciers are expected to provoke cascading effects in the region, which would affect water availability (amount seasonality), biodiversity (endemic species, predator-prey relations) and ecosystem boundary shifts (tree-line movements, highelevation ecosystem changes). This will also have environmental and social impacts that likely increase uncertainty in water supply and agricultural production for human populations ${ }^{209}$. Some studies demonstrate that Himalayan production systems are already declining due to various drivers, as reported by Tiwari and Joshi ${ }^{210}$ for the Central Himalayas and by Sharma et al. ${ }^{211}$ for the Sikkim Himalaya. These drivers are often climate change related, but there may be also a nexus to socioeconomic developments and/or institutional/governance aspects. 


\section{Synthesis of key impacts}

Across the IHR, mean temperature has increased over the past century at a rate that far exceeds the global average, while changes in precipitation show heterogeneous patterns and no clear trends at the regional scale are available. Resulting impacts on the cryosphere are seen in the glaciers and snow cover. Warming has driven widespread shrinkage of glaciers, and corresponding formation and enlargement of thousands of glacier lakes. While catastrophic outburst events from these lakes have been rarely documented in the IHR, several critically dangerous lakes have been identified, and in general, the outburst potential is expected to increase as glacial lakes continue to expand over the 21 st century. Snow-cover data are relatively scarce, but nevertheless, a general decline in snow cover has been observed since the 1960 s, with more variable trends since 2000. Permafrost, as the subsurface component of the cryosphere, has only recently become a focus of systematic studies in the IHR, and as such, there is currently insufficient evidence to link warming and thawing of permafrost to impacts. Floods and landslides have caused particular devastation across several Indian Himalayan states, and are clearly linked to weather and climate extremes. However, the observed increase in flood and landslide events over the past few decades must be viewed in the broader context of anthropogenic effects such as deforestation, road-cutting, increasing exposure of people and assets, and other poor land-use practices that have become evident. Nevertheless, in some catchments there is evidence that both heavy rainfall-triggering events and flood frequencies have increased over the past several decades compared to earlier period documented in long-term palaeo archives.

In general, changes in climate, when coupled with other socio-economic drivers of changes, are expected to have significant impacts on lives and livelihoods across the IHR (Supplementary Figure 5). For some catchments or villages, this has been clearly demonstrated, with crop failure and loss of agricultural productivity linked to changes in hydrological regimes and impacts of extreme weather (both floods and droughts). Likewise, for specific catastrophic events, far-reaching societal impacts have been documented. For example, following the 2013 flooding in Uttarakhand, which has been linked to extreme rainfall, snowmelt and breach of a glacier lake, there was a $85 \%$ reduction in tourism, with an estimated loss of US\$ 1850 million to the State's tourism sector ${ }^{212,213}$. In fact, the impacts of lake outbursts, flash floods and landslides on mountain communities and livelihoods, and transport and energy infrastructure are among the most prominent features of climate and cryosphere changes. The energy sector faces particular challenges. Since India's energy consumption increased by $51 \%$ between 2000 and 2010 and is likely to continue to experience substantial growth, further development of hydropower in the IHR is therefore a national priority. However, but both the existing and planned hydropower plants are exposed to potential outburst floods from glacial lakes, often with 10 to $>100$ lakes upstream of single plants ${ }^{214}$. Some recent disasters have highlighted the transboundary nature of climate impacts in the Himalaya, with LLOFs in 2000 and 2005 originating in Tibet, causing loss of life and substantial economic impact over $100 \mathrm{~km}$ downstream in the Indian State of Himachal Pradesh ${ }^{185}$. Hence, monitoring and exchange of knowledge needs to take place across political boundaries, guided by international best practices.

Overall, systematic studies linking climate change in the IHR with downstream impacts and risks are lacking, and studies have been seriously hampered by limitations in monitoring, data availability and knowledge exchange. The sparsity and paucity of hydro-meteorological observations over the IHR are crucial limitations, with most stations located in the valley bottoms, hence unrepresentative of the high alpine areas ${ }^{26,215}$. In addition, the coarse representation of high-altitude topography/mountains in climate models limits understanding of present as well as the future climate, and RCMs are still not capable of resolving precipitation distribution over the IHR due to high uncertainties with increased greenhouse concentration $^{216,217}$. Heterogeneity in results relating to precipitation changes may be attributed to the dataset, methodology, parameterization scheme used in data reconstruction and model simulation, and the domain of study chosen for the analysis. In addition, various model results have defined uncertainties embedded within them, and hence these results need to be used with utmost care for hydrological and glaciological studies. Improvement in model parameterization and increased observational data will thus play an important role in better understanding of rainfall distribution over the IHR and related impacts at present as well in future.

In case of glacier and snow cover studies, in situ data need to be strengthened as the basis for improved model$\operatorname{ling}^{202}$ and further ice-core studies are needed to ascertain past snow-ice evolution. Further, regional estimates on variation of the derived snow parameters (such as snowline altitude, snow depth and snow-water equivalent) need to be made available for the wider research community, and regional variations in glacier response need to be addressed in detail focusing on causative factors, including regional climate feedbacks relating to black carbon. The World Meteorological Organization lists permafrost as an essential climate variable and some encouraging firm steps have been taken by the national, regional and international agencies to promote permafrost research in the $\mathrm{IHR}^{142}$.

\section{Conclusion and recommendations}

Future warming over the IHR is projected to exceed $2.5^{\circ} \mathrm{C}$ by the end of 21 st century, based on 129 -yr period 
(1971-2099) analysis, even under low greenhouse gas emission scenarios, and consistent increases in monsoon precipitation are expected. Furthermore, studies point out an increase in the occurrence of extreme phenomena such as floods, which when combined with increased human pressure on the natural environment and land-use degradation in the region, have in some instances led to catastrophic consequences.

Limitations in spatial and temporal data coverage, and heterogeneous research methodologies have been identified as key factors leading to uncertainty in observed and projected impacts of climate change in the IHR. In this regard, we recommend improved coordination of research activities across institutional divides, facilitated at the national level through programmes that support and enhance cooperation. India is a world leader in remote sensing technology, and India Meteorological Department has invested significantly in improved monitoring of rainfall over mountain regions. Yet, there are often difficulties for researchers to access such data.

Diversity in research approaches and methodologies, and the critical debate over it, are important, but as seen in the example of GLOFs, different methodologies can lead to vastly different implications for assessed levels of hazard and risk which eventually and occasionally can result in confusion at the level of decision-making. Hence, we call for regular and coordinated reassessment of such threats, to use latest best practices, and furthermore, to account for the fact that environmental and societal baseline conditions are rapidly changing. International collaboration is also seen as important factor for strengthening institutional and scientific capacities in the IHR. For example, mountainous countries such as Switzerland have a long history of responding to the challenges of climate change, therefore experiences may be shared with Indian counterparts on both academic and political levels. Indian science has a broader role to play here, as a leading knowledge partner in the wider Himalayan region. This is particularly important, given that many potential downstream impacts are far-reaching and transboundary in nature. Meanwhile, at the local level, there are opportunities to engage communities directly in the knowledgegeneration process to better understand observed changes, timing and magnitude of impacts at the ground level. Such 'citizen science' activities are growing internationally, for example, with landslide-mapping initiatives based on smartphone apps. Finally, we highlight the importance of interdisciplinary approaches that are required to truly understand and address complex upland - lowland linkages driven by climate change and additional socio-economic stressors. This applies for all sectors, but undoubtedly becomes most pronounced when considering climate change impacts on rural livelihoods. We recommend bottom-up approaches, starting with a comprehensive framing of social dimensions and identifying potential risks through stakeholder discussions, before progressing to physical modelling and assessment of how such risks will be influenced by climate and related biophysical impacts ${ }^{218}$.

Considering wide-ranging ways in which societies interact with and depend upon mountain environments, improved systematic and coordinated monitoring across the IHR, feeding into comprehensive and interdisciplinary assessment approaches, will be essential to ensure that local adaptation decisions are evidence-based, take diverse sources of knowledge into account and are well supported by latest scientific understanding.

1. Kapos, V., Rhind, J., Edwards, M., Price, M. F. and Ravilious, C., Developing a map of the world's mountain forests. In Forests in Sustainable Mountain Development: A State-of-Knowledge Report for 2000 (eds Price, M. F. and Butt, N.), CAB International, Wallingford, UK, 2000, pp. 4-9.

2. Beniston, M., Mountain weather and climate: a general overview and a focus on climatic change in the Alps. Hydrobiologia, 2006, 562(1), 3-16.

3. Rangwala, I. and Miller, J. R., Climate change in mountains: a review of elevation-dependent warming and its possible causes. Climatic Change, 2012, 114(3-4), 527-547.

4. Gautam, R., Hsu, N. C., Lau, K. M., Tsay, S. C. and Kafatos, M., Enhanced pre-monsoon warming over the Himalayan-Gangetic region from 1979 to 2007. Geophys. Res. Lett., 2009, 36(7), doi:10.1029/2009GL037641.

5. Barnett, T. P., Adam, J. C. and Lettenmaier, D. P., Potential impacts of a warming climate on water availability in snowdominated regions. Nature, 2005, 438(7066), 303-309.

6. Messerli, B. and Ives, J. D., Mountains of the World, et Londres, New York, USA, 1997.

7. Beniston, M., Mountain Environments in Changing Climates, Routledge, London, UK, 1994.

8. Meier, M. F., Dyurgerov, M. B. and McCabe, G. J., The health of glaciers: recent changes in glacier regime. Climate Change, 2003, 59, 123-135.

9. Bradley, R. S., Vuille, M., Diaz, H. F. and Vergara, W., Threats to water supplies in the tropical Andes. Science, 2006, 312(5781), 1755-1756.

10. IPCC, Summary for policymakers. In Climate Change 2007: The Physical Science Basis (eds Solomon, S. et al.), Contribution of Working Group I to the Fourth Assessment Report of the Intergovernmental Panel on Climate Change, Cambridge University Press, Cambridge, UK, 2007.

11. IPCC, Climate Change 2013: The Physical Science Basis, Contribution of Working Group I to the Fifth Assessment Report of the Intergovernmental Panel on Climate Change (eds Stocker, T. F. et al.), Cambridge University Press, Cambridge, UK, 2013, p. 1535; doi:10.1017/CBO9781107415324.

12. IPCC, Summary for policymakers. In Climate Change 2014: Impacts, Adaptation, and Vulnerability. Part A: Global and Sectoral Aspects (eds Field, C. B. et al.), Contribution of Working Group II to the Fifth Assessment Report of the Intergovernmental Panel on Climate Change, Cambridge University Press, Cambridge, UK, 2014, pp. 1-32.

13. Vaughan, D. G. et al., Observations: cryosphere. In Climate Change, The Physical Science Basis (eds Stocker, T. F. et al.), Contribution of Working Group I to the Fifth Assessment Report of the Intergovernmental Panel on Climate Change, Cambridge University Press, Cambridge, UK, 2013, pp. 317-382.

14. Cramer, W. et al., Detection and attribution of observed impacts. In Climate Change 2014: Impacts, Adaptation, and Vulnerability. Part A: Global and Sectoral Aspects, Contribution of Working 
Group II to the Fifth Assessment Report of the Intergovernmental Panel on Climate Change (eds Field, C. B. et al.), Cambridge University Press, Cambridge, UK, 2014, pp. 979-1037.

15. HIMAP, Unravelling Climate Change in the Hindu Kush Himalaya: Rapid Warming in the Mountains and Increasing Extremes. In The Hindu Kush Himalaya Assessment: Mountains, Climate Change, Sustainability and People (eds Wester et al.), Springer, 2019, pp. 57-91; https://doi.org/10.1007/978-3-319-92288-1_3.

16. Bolch, T. et al., The state and fate of Himalayan glaciers. Science, 2012, 336(6079), 310-314; 10.1126/science.1215828.

17. Brun, F., Berthier, E., Wagnon, P., Kääb, A. and Treichler, D., A spatially resolved estimate of High Mountain Asia glacier mass balances from 2000 to 2016. Nature Geosci., 2017, 10(9), 668673; doi: 10.1038/NGEO2999.

18. Viviroli, D., Dürr, H. H., Messerli, B., Meybeck, M. and Weingartner, R., Mountains of the world, water towers for humanity: typology, mapping, and global significance. Water Resour. Res., 2007, 43, W07447.

19. Immerzeel, W. W., Van Beek, L. P. and Bierkens, M. F., Climate change will affect the Asian water towers. Science, 2010, 328(5984), 1382-1385.

20. Lutz, A. F., Immerzeel, W. W., Shrestha, A. B. and Bierkens, M. F. P., Consistent increase in High Asia's runoff due to increasing glacier melt and precipitation. Nature Climate Change, 2014, 4, 587-592; doi:10.1038/nclimate2237.

21. Shrestha, A. B., Wake, C. P., Mayewski, P. A. and Dibb, J. E., Maximum temperature trends in the Himalaya and its vicinity. An analysis based on temperature records from Nepal for the period 1971-94. J. Climate, 1999, 12, 2775-2787.

22. Hingane, L. S., Rupa Kumar, K. and Ramana Murty, B. V., Long-term trends of surface air temperature in India. Int. J. Climatol., 1985, 5(5), 521-528.

23. Tsering, K., Constructing future climate scenarios of Bhutan. In Project report on climate change vulnerability and adaptation study for rice production in Bhutan, Climate change studies in Bhutan, Ministry of Agriculture, Bhutan, 2003.

24. Ohmura, A., Enhanced temperature variability in high-altitude climate change. Theor. Appl. Climatol., 2012, 110(4), 499-508.

25. Rangwala, I., Miller, J. R., Russell, G. L. and Xu, M., Using a global climate model to evaluate the influences of water vapor, snow cover and atmospheric aerosol on warming in the Tibetan Plateau during the twenty-first century. Climate Dyn., 2010, 34(6), 859-872.

26. Fowler, H. and Archer, D. R., Conflicting signals of climatic change in the Upper Indus Basin. J. Climate, 2006, 19(17), 4276-4293.

27. Du, M., Kawashima, S., Yonemura, S., Zhang, X. and Chen, S., Mutual influence between human activities and climate change in the Tibetan Plateau during recent years. Global Planet. Change, 2004, 41(3), 241-249.

28. Dimri, A. P. and Dash, S. K., Wintertime climatic trends in the western Himalayas. Climatic Change, 2012, 111(3-4), 775-800.

29. Beniston, M., Diaz, H. F. and Bradley, R. S., Climatic change at high elevation sites: an overview. Climatic Change, 1997, 1-19.

30. Liu, X., Cheng, Z., Yan, L. and Yin, Z. Y., Elevation dependency of recent and future minimum surface air temperature trends in the Tibetan Plateau and its surroundings. Global Planet. Change, 2009, 68(3), 164-174.

31. MRI Mountain Research Initiative Elevation Dependent Warming Working Group, Elevation-dependent warming in mountain regions of the world. Nat. Climate Change, 2015, 5, 424-430; doi:10.1038/nclimate2563.

32. Nengker, T., Choudhary, A. and Dimri, A. P., Assessment of the performance of CORDEX-SA experiments in simulating seasonal mean temperature over the Himalayan region for the present climate: Part I. Climate Dyn., 2017, 50(7-8), 1-31; doi:10.1007/ s00382-017-3597-x.
33. Choudhary, A. and Dimri, A. P., Performance of an ensemble of CORDEX-SA simulations in representing maximum and minimum temperature over the Himalayan region. Theor. Appl. Climatol., 2018; doi:10.1007/s00704-018-2532-3.

34. Rajbhandari, R., Shrestha, A. B., Kulkarni, A., Patwardhan, S. K. and Bajracharya, S. R., Projected changes in climate over the Indus river basin using a high resolution regional climate model (PRECIS). Climate Dyn., 2015, 44(1-2), 339-357.

35. Panday, P. K., Thibeault, J. and Frey, K. E., Changing temperature and precipitation extremes in the Hindu Kush-Himalayan region: an analysis of CMIP3 and CMIP5 simulations and projections. Int. J. Climatol., 2015, 35(10), 3058-3077.

36. Sanjay, J., Krishnan, R., Shrestha, A. B., Rajbhandari, R. and Ren, G. Y., Downscaled climate change projections for the Hindu Kush Himalayan region using CORDEX South Asia regional climate models. Adv. Climate Change Res., 2017, 8(3), 185-198.

37. Rajbhandari, R., Shrestha, A. B., Nepal, S., Wahid, S. and Ren, G. Y., Extreme climate projections over the transboundary Koshi River Basin using a high resolution regional climate model. $A d v$. Climate Change Res., 2017, 8, 199-211; https://doi.org/10.1016/ j.accre.2017.08.006.

38. Nengker, T., Choudhary, A. and Dimri, A. P., Assessment of the performance of CORDEX-SA experiments in simulating seasonal mean temperature over the Himalayan region for the present climate: part I. Climate Dyn., 2018, 50(7-8), 2411-2441.

39. Dimri, A. P., Chevuturi, A., Niyogi, D., Thayyen, R. J., Ray, K., Tripathi, S. N., Pandey, A. K. and Mohanty, U. C., Cloudbursts in Indian Himalayas: a review. Earth-Sci. Rev., 2017, 198, 1-23; https://doi.org/10.1016/j.earscirev.2017.03.006.

40. Dimri, A. P., Kumar, D., Choudhary, A. and Maharana, P., Future changes over the Himalayas: Maximum and minimum temperature. Global Planet. Change, 2018, 162, 212-234; https://doi.org/10.1016/j.gloplacha.2018.01.015.

41. Kumar, P., Kotlarski, S., Moseley, C., Sieck, K., Frey, H., Stoffel, M. and Jacob, D., Response of Karakoram-Himalayan glaciers to climate variability and climatic change: a regional climate model assessment. Geophys. Res. Lett., 2015, 42(6), 1818-1825.

42. Barry, R. G., Mountain Weather and Climate, Cambridge University Press, Cambridge, UK, 2008, 3rd edn.

43. Dimri, A. P., Impact of horizontal model resolution and orography on the simulation of a western disturbance and its associated precipitation. Meteorol. Appl., 2004, 11(2), 115-127.

44. Dimri, A. P. and Mohanty, U. C., Simulation of mesoscale features associated with intense western disturbances over western Himalayas. Meteorol. Appl., 2009, 16(3), 289-308.

45. Joshi, S., Kumar, K., Joshi, V. and Pande, B., Rainfall variability and indices of extreme rainfall-analysis and perception study for two stations over Central Himalaya, India. Nat. Hazards, 2014, 72(2), 361-374.

46. Shrestha, A. B., Bajracharya, S. R., Sharma, A. R., Duo, C. and Kulkarni, A., Observed trends and changes in daily temperature and precipitation extremes over the Koshi river basin 1975-2010. Int. J. Climatol., 2017, 37(2), 1066-1083.

47. Yao, T. et al., Different glacier status with atmospheric circulations in Tibetan Plateau and surroundings. Nature Clim. Change, 2012, 2, 663-667; 10.1038/NCLIMATE1580.

48. Shrestha, A. B., Wake, C. P., Dibb, J. E. and Mayewski, P. A., Precipitation fluctuations in the Nepal Himalaya and its vicinity and relationship with some large scale climatological parameters. Int. J. Climatol., 2000, 20(3), 317-327.

49. Singh, P. and Kumar, N., Effect of orography on precipitation in the western Himalayan region. J. Hydrol., 1997, 199(1-2), 183206.

50. Ménégoz, M., Gallée, H. and Jacobi, H. W., Precipitation and snow cover in the Himalaya: from reanalysis to regional climate simulations. Hydrol. Earth Syst. Sci., 2013, 17(10), 3921-3936. 
51. Dimri, A, P., Niyogi, D., Barros, A. P., Ridley, J., Mohanty, U. C., Yasunari, T. and Sikka, D. R., Western disturbances: a review. Rev. Geophys., 2015, 53(2), 225-246.

52. Guhathakurta, P., Sreejith, O. P. and Menon, P. A., Impact of climate change on extreme rainfall events and flood risk in India J. Earth Syst. Sci., 2011, 120(3), 359-373.

53. Joshi, V. and Kumar, K., Extreme rainfall events and associated natural hazards in Alaknanda valley, Indian Himalayan region. J. Mountain Sci., 2006, 3(3), 228-236.

54. Rajeevan, M., Bhate, J. and Jaswal, A. K., Analysis of variability and trends of extreme rainfall events over India using 104 years of gridded daily rainfall data. Geophys. Res. Lett., 2008, 35(18), https://doi.org/10.1029/2008GL035143.

55. Zhan, Y. J. et al., Changes in extreme precipitation events over the Hindu Kush Himalayan region during 1961-2012. Adv. Climate Change Res., 2017, 8(3), 166-175.

56. Madhura, R. K., Krishnan, R., Revadekar, J. V., Mujumdar, M. and Goswami, B. N., Changes in western disturbances over the Western Himalayas in a warming environment. Climate Dyn., 2015, 44(3-4), 1157-1168.

57. Singh, R. B. and Sen Roy, S., Climate variability and hydrological extremes in a Himalayan catchment. In ERB and Northern European Friend Project 5 Conference, Slovakia, 2002.

58. Singh, R. B. and Mal, S., Trends and variability of monsoon and other rainfall seasons in Western Himalaya, India. Atmos. Sci. Lett., 2014, 15(3), 218-226.

59. Mukherjee, S., Joshi, R., Prasad, R. C., Vishvakarma, S. C. and Kumar, K., Summer monsoon rainfall trends in the Indian Himalayan region. Theor. Appl. Climatol., 2015, 121(3-4), 789-802.

60. Bharti, V., Investigation of extreme rainfall events over the northwest Himalaya Region using satellite data. University of Twente, Faculty of Geo-Information and Earth Observation, 2015.

61. Kumar, V. and Jain, S. K., Trends in seasonal and annual rainfall and rainy days in Kashmir Valley in the last century. Quaternary Int.., 2010, 212(1), 64-69.

62. Qing-Long, Y. et al., An overview of studies of observed climate change in the Hindu Kush Himalayan (HKH) region. $\mathrm{Adv}$. Climate Change Res., 2017, 8(3), 141-147; https://doi.org/ 10.1016/j.accre.2017.04.001.

63. Gautam, M. R., Timilsina, G. R. and Acharya, K., Climate change in the Himalayas: current state of knowledge. Policy Research Working Paper No. WPS 6516. World Bank, Washington, DC, 2013; http://documents.worldbank.org/curated/en/421301468350108330/Climate-change-in-the-Himalayas-current-state-ofknowledge

64. Dimri, A. P., Yasunari, T., Wiltshire, A., Kumar, P., Mathison, C., Ridley, J. and Jacob, D., Application of regional climate models to the Indian winter monsoon over the western Himalayas. Sci. Total Environ., 2013, 468, S36-S47.

65. Dimri, A. P. and Ganju, A., Wintertime seasonal scale simulation over Western Himalaya using RegCM3. Pure Appl. Geophys., 2007, 164(8), 1733-1746.

66. Ménégoz, M., Gallée, H. and Jacobi, H. W., Precipitation and snow cover in the Himalaya: from reanalysis to regional climate simulations. Hydrol. Earth Syst. Sci., 2013, 17, 3921-3936; https://doi.org/10.5194/hess-17-3921-2013.

67. Ghimire, S., Choudhary, A. and Dimri, A. P., Assessment of the performance of CORDEX-South Asia experiments for monsoonal precipitation over the Himalayan region during present climate: part I. Climate Dyn., 2015, 1-24.

68. Choudhary, A., Dimri, A. P. and Maharana, P., Assessment of CORDEX-SA experiments in representing precipitation climatology of summer monsoon over India. Theor. Appl. Climatol., 2017, 1-25; https://doi.org/10.1007/s00704-017-2274-7.

69. Palazzi, E., Hardenberg, J. V. and Provenzale, A., Precipitation in the Hindu-Kush Karakoram Himalaya: Observations and future scenarios. J. Geophys. Res: Atmos., 2013, 118(1), 85-100.
70. Dash, S. K., Mishra, S. K., Pattnayak, K. C., Mamgain, A. Mariotti, L., Coppola, E., Giorgi, F. and Giuliani, G., Projected seasonal mean summer monsoon over India and adjoining regions for the twenty-first century. Theor. Appl. Climatol., 2015, 122(3-4), 581-593.

71. Palazzi, E., von Hardenberg, J., Terzago, S. and Provenzale, A., Precipitation in the Karakoram-Himalaya: a CMIP5 view. Climate Dyn., 2015, 45(1-2), 21-45.

72. Oh, S. G., Park, J. H., Lee, S. H. and Suh, M. S., Assessment of the RegCM4 over East Asia and future precipitation change adapted to the RCP scenarios. J. Geophys. Res.: Atmos., 2014, 119(6), 2913-2927.

73. Kulkarni, A., Patwardhan, S., Kumar, K. K., Ashok, K. and Krishnan, R., Projected climate change in the Hindu KushHimalayan region by using the high-resolution regional climate model PRECIS. Mountain Res. Dev., 2013, 33(2), 142-151.

74. Raina, V. and Srivastava, D., Glacier Atlas of India, Geological Society of India, Bangalore, 2008, pp. 1-316.

75. Kulkarni, A. V. and Karyakarte, Y., Observed changes in Himalayan glaciers. Curr. Sci., 2014, 106(2), 237-244.

76. Pfeffer, W. et al., The Randolph Glacier Inventory: a globally complete inventory of glaciers. J. Glaciol., 2014, 60(221), 537-552.

77. Bajracharya, S. R. and Shrestha, B., The status of glaciers in the Hindu Kush-Himalayan region. International Centre for Integrated Mountain Development (ICIMOD), Kathmandu, Nepal, 2011.

78. Bolch, T., Buchroithner, M. F., Pieczonka, T. and Kunert, A., Planimetric and volumetric glacier changes in Khumbu Himalaya since 1962 using Corona, Landsat TM and ASTER data. J. Glaciol., 2008, 54 (187), 592-600; 10.3189/002214308786570782.

79. Scherler, D., Bookhagen, B. and Strecker, M. R., Spatially variable response of Himalayan glaciers to climate change affected by debris cover. Nature Geosci., 2011, 4, 156-159; 10.1038 NGEO1068.

80. Benn, D. I., Bolch, T., Hands, K., Gulley, J., Luckman, A., Nicholson, L. I., Quincey, D., Thompson, S., Toumi, R. and Wiseman, S., Response of debris-covered glaciers in the Mount Everest region to recent warming, and implications for outburst flood hazards. Earth-Sci. Rev., 2012, 114(1-2), 156-174; 10.1016/j.earscirev.2012.03.008.

81. Gardelle, J., Berthier, E., Arnaud, Y. and Kääb, A., Region-wide glacier mass balances over the Pamir-Karakoram-Himalaya during 1999-2011. Cryosphere, 2013, 7, 1263-1286; 10.5194/tc-71263-2013.

82. Bhambri, R. and Bolch, T., Glacier mapping: a review with special reference to the Indian Himalayas. Prog. Phys. Geog., 2009, 33(5), 672-704; 10.1177/03091333309348112.

83. Hewitt, K., Glacier change, concentration, and elevation effects in the Karakoram Himalaya, Upper Indus Basin. Mount Res Dev., 2011, 33(3), 188-200; 10.1659/MRD-JOURNAL-D-11-00020.1.

84. Mayewski, P. A. and Jeschke, P. A., Himalayan and transHimalayan glacier fluctuations since AD 1812. Arct. Alp. Res., 1979, 11(3), 267-287.

85. Raina, V., Himalayan Glaciers: A State-of-art Review of Glacial Studies, Glacial Retreat and Climate Change, New Delhi, 2009, pp. 1-56.

86. Kulkarni, A. V., Rathore, B. P., Singh, S. K. and Bahuguna, I. M., Understanding changes in the Himalayan cryosphere using remote sensing techniques. Int. J. Remote Sensing, 2011, 32(3), 601-615; 10.1080/01431161.2010.517802.

87. Racoviteanu, A. et al., Himalayan glaciers (India, Bhutan, Nepal): satellite observations of thinning and retreat. In Global Land Ice Measurements from Space (eds Kargel, J. S. et al.), Springer, Berlin, Heidelberg, 2014, pp. 549-582.

88. Racoviteanu, A. E., Arnaud, Y., Williams, M. W. and Manley, W. F., Spatial patterns in glacier characteristics and area changes from 1962 to 2006 in the Kanchenjunga-Sikkim area, eastern 
Himalaya. Cryosphere, 2015, 9(2), 505-523; 10.5194/tc-9-5052015.

89. Bhambri, R., Bolch, T., Chaujar, R. K. and Kulshreshtha, S. C., Glacier changes in the Garhwal Himalayas, India, 1968-2006 based on remote sensing. J. Glaciol., 2011, 57(203), 543-556.

90. Schmidt, S. and Nüsser, M., Changes of High Altitude Glaciers from 1969 to 2010 in the Trans-Himalayan Kang Yatze Massif, Ladakh, Northwest India. Arct. Antarct. Alp. Res., 2012, 44(1), 107-121; 10.1657/1938-4246-44.1.

91. Kraaijenbrink, P. D. S., Bierkens, M. F. P., Lutz, A. F. and Immerzeel, W. W., Impact of a global temperature rise of 1.5 degrees Celsius on Asia's glaciers. Nature, 2017, 549, 257-260.

92. Bhambri, R., Bolch, T., Kawishwar, P., Dobhal, D., Srivastava D. and Pratap, B., Heterogeneity in glacier response in the Shyok valley, northeast Karakoram. Cryosphere, 2013, 7, 1384-1398; $10.5194 / \mathrm{tc}-7-1385-2013$.

93. Minora, U. et al., Glacier area stability in the Central Karakoram National Park (Pakistan) in 2001-2010: The 'Karakoram Anomaly' in the spotlight. Prog. Phys. Geogr., 2016; 10.1177/ 0309133316643926

94. Bolch, T., Pieczonka, T., Mukherjee, K. and Shea, J., Brief communication: Glaciers in the Hunza catchment (Karakoram) have been nearly in balance since the 1970s. Cryosphere, 2017, 11(1), 531-539; 10.5194/tc-11-531-2017.

95. Gardelle, J., Berthier, E. and Arnaud, Y., Slight gain of mass by Karakoram glaciers in the early 21 st century. Nature Geosci., 2012, 5, 322-325; 10.1038/ngeo1450.

96. Zhou, Y., Li, Z. and Li, J. I., Slight glacier mass loss in the Karakoram region during the 1970 s to 2000 revealed by KH-9 images and SRTM DEM. J. Glaciol., 2017, 63(238), 331-342; 10.1017/jog.2016.142.

97. Copland, L. et al., Expanded and recently increased glacier surging in the Karakoram. Arct. Antarct. Alp. Res., 2011, 43(4), 503$516 ; 10.1657 / 1938-4246-43.4 .503$.

98. Rank, M. and Braun, M., Glacier elevation and mass changes over the central Karakoram region estimated from TanDEM-X and SRTM/X-SAR digital elevation models. Ann. Glaciol., 2016, 57(71), 273-281; 10.3189/2016AoG71A024.

99. Dehecq, A., Gourmelen, N. and Trouve, E., Deriving large-scale glacier velocities from a complete satellite archive: application to the Pamir-Karakoram-Himalaya. Remote Sensing Environ., $2015,16,55-66$.

100. Heid, T. and Kääb, A., Repeat optical satellite images reveal widespread and long term decrease in land-terminating glacier speeds. Cryosphere, 2012, 6, 467-478; 10.5194/tc-6-467-2012.

101. Vincent, C. et al., Balanced conditions or slight mass gain of glaciers in the Lahaul and Spiti region (northern India, Himalaya) during the nineties preceded recent mass loss. Cryosphere, 2013, 7, 569-582.

102. Gardner, A. S. et al., A reconciled estimate of glacier contributions to sea level rise: 2003 to 2009. Science, 2013, 340, 852857.

103. Garg, P. K., Shukla, A. and Jasrotia, A. S., Influence of topography on glacier changes in the central Himalaya, India. Global Planet Change, 2017, 156, 196-212.

104. Kapnick, S. B., Delworth, T. L., Ashfaq, M., Malyshev, S. and Milly, P. C. D., Snowfall less sensitive to warming in Karakoram than in Himalayas due to a unique seasonal cycle. Nature Geosci., 2014, 7(11), 834-840.

105. Salerno, F., Thakuri, S., Tartari, G., Nuimura, T., Sunako, S., Sakai, A. and Fujita, K., Debris-covered glacier anomaly? Morphological factors controlling changes in the mass balance, surface area, terminus position, and snow line altitude of Himalayan glaciers. Earth Planet. Sci. Lett., 2017, 471, 19-31; 10.1016/j.eps1.2017.04.039.

106. Wang, J. and Li, W., Comparison of methods of snow cover mapping by analyzing the solar spectrum of satellite remote sens- ing data in China. Int. J. Remote Sensing, 2003, 24(21), 41294136.

107. Rango, A. and Martinec, J., Accuracy of snowmelt runoff simulation. Nordic Hydrol., 1981, 12, 265-274.

108. Baumgartner, M. F., Martinec, J. and Siedel, K., Large-area deterministic simulation of natural runoff from snowmelt based on Landsat MSS data. IEEE Trans. Geosci. Remote Sensing, 1986, 24(6), 1013-1016.

109. Haeberli, W., Kääb, A., VonderMühll, D. and Teysseire, P., Prevention of outburst floods from periglacial lakes at Grubengletscher, Valais, Swiss Alps. J. Glaciol., 2001, 47(156), 111-122.

110. Oerlemans, J., Dyurgerov, M. and Van de Wal, R. S. W., Reconstructing the glacier contribution to sea-level rise back to 1850 . Cryosphere Discuss, 2007, 1, 59-65; www.the-cryospherediscuss.net/1/77/2007/

111. Quincey, D. J., Lucas, R. M., Richardson, S. D., Glasser, N. F., Hambrey, M. J. and Reynolds, J. M., Optical remote sensing techniques in high-mountain environments: application to glacial hazards. Prog. Phys. Geogr., 2005, 29(4), 475-505.

112. Khromova, T. E., Osipova, G. B., Tsvetkov, D. G., Dyurgerov, M. B. and Barry, R. G., Changes in glacier extent in the eastern Pamir, Central Asia, determined from historical data and ASTER imagery. Remote Sensing Environ., 2006, 102(1), 24-32.

113. Kulkarni, A. V., Bahuguna, I. M., Rathore, B. P., Singh, S. K., Randhawa, S. S., Sood, R. K. and Dhar, S., Glacier retreat in Himalayas using Indian Remote Sensing satellite data. Curr Sci., 2007, 92(1), 69-74.

114. Konz, M. et al., Calibration of a distributed hydrological model for simulations of remote glacierized Himalayan catchments using MODIS snow cover data. In Global Change: Facing Risks and Threats to Water Resources, Proceedings of the Sixth World FRIEND Conference, Fez, Morocco, October 2010, International Association of Hydrological Sciences, IAHS Publication (340), Wallingford, UK, 2010, pp. 465-473.

115. Rikiishi, K. and Nakasato, H., Height dependence of the tendency for reduction in seasonal snow cover in the Himalaya and the Tibetan Plateau region, 1966-2001. Ann. Glaciol., 2006, 43(1), 369377.

116. Gurung, D. R., Giriraj, A., Anug, K. S., Shreshtha, B. and Kulkarni, A. V., Snow-cover mapping and monitoring in the HinduKush-Himalayas. ICIMOD, Kathmandu, Nepal, 2011.

117. Singh, S. K., Rathore, B. P., Bahuguna, I. M. and Ajai, Snow cover variability in the Himalayan-Tibetan region. Int. J. Climatol., 2014, 34(2), 446-452.

118. Immerzeel, W. W., Droogers, P., de Jong, S. M. and Bierkens, M. F. P., Large-scale monitoring of snow cover and runoff simulation in Himalayan river basins using remote sensing. Remote Sensing Environ., 2009, 113(1), 40-49; doi:10.1016/j.rse.2008.08.010.

119. Mukhopadhyay, B., Signature and hydrologic consequences of climate change within the upper-middle Brahmaputra Basin. Hydrol. Proc., 2013, 27, 2126-2143.

120. Rathore, B. P. et al., Spatio-temporal variability of snow cover in Alaknanda, Bhagirathi and Yamuna sub-basins, Uttarakhand Himalaya. Curr. Sci., 2015, 108(7), 1375-1380.

121. Hahn, D. G. and Shukla, J., An apparent relationship between Eurasian snow cover and Indian monsoon rainfall. J. Atmos. Sci., 1976, 33, 2461-2462.

122. Parthasarathy, B. and Pant, G. B., Indian summer monsoon and Eurasian snow cover. In Western Himalayas, Vol. I, Gyanodaya Prakash Publishers, New Delhi, 1987, pp. 61-71.

123. Bamzai, A. S. and Shukla, J., Relation between Eurasian snow cover, snow depth and the Indian summer monsoon: an observational study. J. Climate, 1999, 12, 3117-3132.

124. Kriplani, R. H., Kulkarni, A. and Sabade, S. S., Western Himalayan snow cover and Indian monsoon rainfall: a re-examination with INSAT and NCEP/NCAR data. Theor. Appl. Climatol., 2003, 74, 1-18. 
125. Menon, S., Koch, D., Beig, G., Sahu, S., Fasullo, J. and Orlikowski, D., Black carbon aerosols and the third polar ice cap. Atmos. Chem. Phys., 2010, 10, 4559-4571.

126. Negi, H. S., Thakur, N. K., Kumar, R. and Kumar, M., Monitoring and evaluation of seasonal snow cover in Kashmir valley using remote sensing, GIS and ancillary data. J. Earth Syst. Sci., 2009, 118(6), 711-720.

127. Kulkarni, A. V., Rathore, B. P., Singh, S. K. and Ajai, Distribution of seasonal snow cover in central and western Himalaya Ann. Glaciol., 2010, 51(54), 123-128.

128. Hasson, S., Lucarini, V., Khan, M. R., Petitta, M., Bolch, T. and Gioli, G., Early 21 st century snow cover state over the western river basins of the Indus River system. Hydrol. Earth Syst. Sci., 2014, 18(10), 4077-4100.

129. Tahir, A. A., Adamowski, J. F., Chevallier, P., Haq, A. U., Terzago, S., Comparative assessment of spatiotemporal snow cover changes and hydrological behavior of the Gilgit, Astore and Hunza River basins (Hindukush-Karakoram-Himalaya region, Pakistan). Meteorol. Atmos. Phys., 2016, 128, 793-811.

130. Westermann, S., Østby, T. I., Gisnås, K., Schuler, T. V. and Etzelmüller, B., A ground temperature map of the North Atlantic permafrost region based on remote sensing and reanalysis data. Cryosphere, 2015, 9(3), 1303-1319.

131. Haeberli, W., Guodong, C., Gorbunov, A. P. and Harris, S. A., Mountain permafrost and climatic change. Permafrost Periglacial Process., 1993, 4(2), 165-174.

132. Cremonese, E. et al., Brief Communication: An inventory of permafrost evidence for the European Alps. Cryosphere, 2011, 5(3), 651-657.

133. Gruber, S., Derivation and analysis of a high-resolution estimate of global permafrost zonation. Cryosphere, 2012, 6(1), 221.

134. Bolch, T. and Christiansen, H. H., Mountains, lowlands, and coasts: the physiography of cold landscapes. In Snow and IceRelated Hazards, Risks, and Disasters, Elsevier Inc., 2014, pp. 201-217; https://doi.org/10.1016/B978-0-12-394849-6.00007-X.

135. Nelson, F. E., (Un)frozen in time. Science, 2003, 299(5613), 1673-1675.

136. Hinzman, L. D. et al., Evidence and implications of recent climate change in northern Alaska and other arctic regions. Climatic Change, 2005, 72(3), 251-298.

137. Zhang, T. et al., Spatial and temporal variability in active layer thickness over the Russian Arctic drainage basin. J. Geophys. Res.: Atmos., 2005, 110(D16).

138. Romanovsky, V. E., Smith, S. L. and Christiansen, H. H., Permafrost thermal state in the polar Northern Hemisphere during the international polar year 2007-2009: a synthesis. Permafrost Periglacial Process., 2010, 21(2), 106-116.

139. Gruber, S. et al., Inferring permafrost and permafrost thaw in the mountains of the Hindu Kush Himalaya region. Cryosphere, 2017, 11(1), 81-99.

140. Rastogi, S. P. and Narayan, S., Permafrost in the Tso Kar Basin, Ladakh. In Proceedings of the Symposium for Snow, Ice and Glaciers, Geological Survey of India Special Publication, 1999, vol. 53, pp. 315-319.

141. Schmid, M. O., Baral, P., Gruber, S., Shahi, S., Shrestha, T., Stumm, D. and Wester, P., Assessment of permafrost distribution maps in the Hindu Kush Himalayan region using rock glaciers mapped in Google Earth. Cryosphere, 2015, 9(6), 2089-2099.

142. Allen, S. K., Fiddes, J., Linsbauer, A., Randhawa, S. S., Saklani, B. and Salzmann, N., Permafrost studies in Kullu district, Himachal Pradesh. Curr Sci., 2016, 11, 257-260.

143. Thayyen, R. J., Ground ice melt in the catchment runoff in the Himalayan cold-arid system (Abstract, 71A1571) In: International Symposium on Glaciology in High-Mountain Asia, International Glaciological Society, Kathmandu, Nepal, 2-6 March 2015.

144. Wünnemann, B., Reinhardt, C., Kotlia, B. S. and Riedel, F., Observations on the relationship between lake formation, perma- frost activity and lithalsa development during the last 20000 years in the Tso Kar Basin, Ladakh, India. Permafrost Periglacial Process., 2008, 19(4), 341-358.

145. Schaphoff, S., Heyder, U., Ostberg, S., Gerten, D., Heinke, J. and Lucht, W., Contribution of permafrost soils to the global carbon budget. Environ. Res. Lett., 2013, 8(1); doi:10.1088/1748-9326/ 8/1/014026.

146. Gardelle, J., Arnaud, Y. and Berthier, E., Contrasted evolution of glacial lakes along the Hindu Kush Himalaya mountain range between 1990 and 2009. Global Planet. Change, 2011, 75, 47-55; doi:10.1016/j.gloplacha.2010.10.003.

147. Ives, J. D., Shrestha, R. B. and Mool, P. K., Formation of glacial lakes in the Hindu Kush-Himalayas and GLOF risk assessment. International Centre for Integrated Mountain Development (ICIMOD), Kathmandu, Nepal, 2010.

148. Worni, R., Huggel, C. and Stoffel, M., Glacial lakes in the Indian Himalayas-from an area-wide glacial lake inventory to on-site and modeling based risk assessment of critical glacial lakes. Sci. Total Environ., 2013; http://dx.doi.org/10.1016/j.scitotenv.2012. 11.043 .

149. Fujita, K., Sakai, A., Takenaka, S., Nuimura, T., Surazakov, A. B., Sawagaki, T. and Yamanokuchi, T., Potential flood volume of Himalayan glacial lakes. Nat. Hazards Earth Syst. Sci., 2013, 13, $1827-1839$.

150. Nie, Y., Sheng, Y., Liu, Q., Liu, L., Liu, S., Zhang, Y. and Song, C., A regional-scale assessment of Himalayan glacial lake changes using satellite observations from 1990 to 2015. Remote Sensing Environ., 2017, 189, 1-3; 10.1016/j.rse.2016.11.008.

151. Nie, Y., Liu, Q. and Liu, S., Glacial lake expansion in the Central Himalayas by Landsat Images, 1990-2010. PLoS ONE, 2013, 8(12), e83973; doi:10.1371/journal.pone.0083973.

152. Carrivick, J. L. and Tweed, F. S., A global assessment of the societal impacts of glacier outburst floods. Global Planet. Change, 2016, 144, 1-16; http://dx.doi.org/10.1016/j.gloplacha. 2016.07.001.

153. Zhang, G., Yao, T., Xie, H., Wang, W. and Yang, W., An inventory of glacial lakes in the Third Pole region and their changes in response to global warming. Global Planet. Change, 2015, 131, 148-157; http://dx.doi.org/10.1016/j.gloplacha.2015.05.013.

154. Singh, R. B. and Kumar, P., Climate change and glacial lake outburst floods in Himachal Himalaya, India. In Climate Change and Biodiversity, Proceedings of IGU Rohtak Conference 1 (eds Singh, M., Singh, R. B. and Hassan, M. I.), Springer, 2014, pp. 3-14.

155. Patel, L. K., Sharma, P., Laluraj, C. M., Thamban, M., Singh, A. and Ravindra, R., A geospatial analysis of Samudra Tapu and Gepang Gath glacial lakes in the Chandra Basin, Western Himalaya. Nat. Hazards, 2017, 86(3), 1275-1290.

156. Rathore, B. P., Singh, S. K., Brahmbhatt, R. M., Bahuguna, I. M., Rajawat, A. S. and Ajai, Monitoring of moraine-dammed lakes: a remote sensing-based study in the Western Himalaya. Curr. Sci., 2015, 109(10), 1843-1849.

157. Randhawa, S., Sood, R., Rathore, B. and Kulkarni, A., MoraineDammed Lakes study in the Chenab and The Satluj River Basins using IRS data. J. Indian Soc. Remote Sensing, 2005, 33, 285 $290 ; 10.1007 / \mathrm{BF} 02990047$.

158. Prakash, C. and Nagarajan, R., Outburst susceptibility assessment of moraine-dammed lakes in Western Himalaya using an analytic Hierarchy process. Earth Surf. Process. Landforms, 2017, 42(14), 2306-2321; doi:10.1002/esp.4185.

159. Raj, K. B. and Kumar, K. V., Inventory of glacial lakes and its evolution in Uttarakhand Himalaya using time series satellite data. J. Indian Soc. Remote Sensing, 2016; doi:10.1007/s12524016-0560-y

160. Jain, S. K., Lohani, A. K., Singh, R. D., Chaudhary, A. and Thakural, L. N., Glacial lakes and glacial lake outburst flood in a Himalayan basin using remote sensing and GIS. Nat. Hazards, 2012, 62, 887-899; doi:10.1007/s11069-012-0120-x. 
161. Jha, L. K. and Khare, D., Detection and delineation of glacial lakes and identification of potentially dangerous lakes of Dhauliganga basin in the Himalaya by remote sensing techniques. Nat. Hazards, 2017, 85, 301-327; doi:10.1007/s11069-016-2565-9.

162. Kumar, B. and Prabhu, M., Impacts of climate change: Glacial lake outburst floods (GLOFs). In Climate Change in Sikkim: Patterns, Impacts and Initiatives, Information and Public Relations Department, Government of Sikkim, Gangtok, 2012.

163. Aggarwal, A., Jain, S. K., Lohani, A. K. and Jain, N., Glacial lake outburst flood risk assessment using combined approaches of remote sensing, GIS and dam break modelling. Geomat. Nat. Hazards Risk, 2013, 7, 1-19; doi:10.1080/19475705.2013. 862573 .

164. Aggarwal, S., Rai, S. C., Thakur, P. and Emmer, A., Inventory and recently increasing GLOF susceptibility of glacial lakes in Sikkim, Eastern Himalaya. Geomorphology, 2017, 295, 39-54; 10.1016/j.geomorph.2017.06.014.

165. Allen, S. K., Linsbauer, A., Randhawa, S. S., Huggel, C., Rana, P. and Kumari, A., Glacial lake outburst flood risk in Himachal Pradesh, India: an integrative and anticipatory approach considering current and future threats. Nat. Hazards, 2016, 84, 17411763; doi:10.1007/s11069-016-2511-x.

166. Richardson, S. D. and Reynolds, J. M., An overview of glacial hazards in the Himalayas. Quaternary Int., 2000, 65, 31-47.

167. Harrison, S. et al., Climate change and the global pattern of moraine-dammed glacial lake outburst floods. Cryosphere, 2018, 12, 1195-1209; https://doi.org/10.5194/tc-12-1195-2018.

168. Raj, K. B. G., Remya, S. N. and Kumar, K. V., Remote sensingbased hazard assessment of glacial lakes in Sikkim Himalaya. Curr. Sci., 2013, 104(3), 359-364.

169. Mason, K., The Chong Khumdan glacier. Himalayan J., 1932, 5, $128-130$.

170. Hewitt, K., Natural dams and outburst floods of the Karakoram Himalaya. JAMS, 1982, 138, 259-269.

171. Das, S., Kar, N. S. and Bandyopadhyay, S., Glacial lake outburst flood at Kedarnath, Indian Himalaya: a study using digital elevation models and satellite images. Nat. Hazards, 2015, 77(2), 769-786; doi:10.1007/s11069-015-1629-6.

172. Coxon, P., Owen, L. and Mitchell, W., A late quaternary catastrophic flood in the Lahul Himalayas. J. Quaternary Sci., 1996, 11, 495-510; 10.1002/(SICI)1099-1417(199611/12)11:6<495: AID-JQS268>3.0.CO;2-M.

173. Sangode, S. J., Phadtare, N. R., Meshram, D. C., Rawat, S. and Suresh, N., A record of lake outburst in the Indus Valley of the Ladakh Himalaya, India. Curr. Sci., 2011, 100, 1712-1718.

174. Allen, S. K., Rastner, P., Arora, M., Huggel, C. and Stoffel, M., Lake outburst and debris flow disaster at Kedarnath, June 2013: hydrometeorological triggering and topographic predisposition. Landslides, 2015, 13(6), 1479-1491; 10.1007/s10346-015-0584-3.

175. Stäubli, A. et al., Analysis of weather- and climate-related disasters in mountain regions using different disaster databases. In Climate Change, Extreme Events and Disaster Risk Reduction (eds Mal, S., Singh, R. B. and Christian, C.), Springer, 2018, pp. 17-41.

176. Kale, V. S., Fluvial geomorphology of Indian rivers: an overview. Prog. Phys. Geogr., 2002, 26(3), 400-433.

177. Gupta, A., Geomorphological effects of floods on Indian rivers. In Flood Studies in India (ed. Kale, V. S.), Geological Society of India, Memoir (41), 1998, pp. 143-153.

178. Gardner, J. S., Natural hazards risk in the Kullu District, Himachal Pradesh, India. Geogr. Rev., 2002, 92, 282-306; doi:10. 1111/j.1931-0846.2002.tb00008.x

179. Gardner, J. S. and Saczuk, E., Systems for hazards identification in high mountain areas: an example from the Kullu District, western Himalaya. J. Mt. Sci., 2004, 1, 115-127; doi:10.1007/ BF02919334.

180. Singh, O. and Kumar, M., Flood events, fatalities and damages in India from 1978 to 2006. Nat. Hazards, 2013, 69, 1815-1834.
181. Ebi, K. L., Woodruff, R., Hildebrand, A. V. and Corvalan, C., Climate change-related health impacts in the Hindu KushHimalayas. EcoHealth, 2007, 4(3), 264-270; doi:10.1007/ s10393-007-0119-z.

182. Pal, S., Juyal, D., Sharma, M., Kotian, S., Negi, V. and Sharma, N., An outbreak of hepatitis A virus among children in a flood rescue camp: a post-disaster catastrophe. Indian J. Med. Microbiol., 2016, 34(2), 233-236; doi:10.4103/0255-0857.180354.

183. Bhattachaiyya, N. N. and Bora, A. K., Floods of the Brahmaputra River in India. Water Int., 1997, 22, 222-229.

184. Gupta, V. and Sah, M. P., Impact of the Trans-Himalayan Landslide Lake Outburst Flood (LLOF) in the Satluj catchment, Himachal Pradesh, India. Nat. Hazards, 2008, 45, 379-390.

185. Ruiz-Villanueva, V., Allen, S., Arora, M., Goel, N. K. and Stoffel, M., Recent catastrophic landslide lake outburst floods in the Himalayan mountain range. Prog. Phys. Geogr., 2016, 41(1), 328; doi:10.1177/0309133316658614.

186. Ray, K., Bhan, S. C. and Bandopadhyay, B. K., The catastrophe over Jammu and Kashmir in September 2014: a meteorological observational analysis. Curr. Sci., 2015, 109(3), 580-591.

187. Gardner, J. S. and Dekens, J., Mountain hazards and the resilience of social-ecological systems: lessons learned in India and Canada. Nat. Hazards, 2007, 41(2), 317-336.

188. Sati, S. P., Sundriyal, Y. P., Rana, N. and Dangwal, S., Recent landslides in Uttarakhand: Nature's fury or human folly. Curr. Sci., 2011, 100(11), 1617-1620.

189. Sati, S. P. and Gahalaut, V. K., The fury of the floods in the north-west Himalayan region: the Kedarnath tragedy. Geomat. Nat. Hazards Risk, 2013, 4, 193-201.

190. Pande, R. K., Landslide problems in Uttaranchal, India: issues and challenges. Disaster Prev. Manage., 2006, 15(2), 247-255; doi:10.1108/09653560610659793.

191. Uniyal, A., Lessons from Kedarnath tragedy of Uttarakhand Himalaya, India. Curr. Sci., 2013, 105, 1472-1473.

192. Singh, O. and Kumar, M., Flood occurrences, damages, and management challenges in India: a geographical perspective. Arab. J. Geosci., 2017, 10(5), 102.

193. Ballesteros-Cánovas, J., Trappmann, D., Shekhar, M., Bhattacharyya, A. and Stoffel, M., Regional flood-frequency reconstruction for Kullu district, Western Indian Himalayas. $J$. Hydrol., 2017, 546, 140-149.

194. Bhutiyani, M. R., Kale, V. S. and Pawar, N. J., Changing stream flow patterns in the rivers of Northwest Himalaya: Implications of global warming in the 20th century. Curr Sci., 2008, 95, 703-708.

195. Kale, V. S., Mishra, S. and Baker, V. R., A 200-year palaeoflood record from Sakarghat, on Narmada, central India. Geol. Soc. India, 1997, 50, 285-288.

196. Ely, L. L., Enzel, Y., Baker, V. R., Kale, V. S. and Mishra, S., Changes in the magnitude and frequency of late Holocene monsoon floods on the Narmada River, central India. Geol. Soc. Am. Bull., 1996, 108(9), 1134-1148.

197. Ballesteros-Cánovas, J. A. et al., Recent flood hazards in Kashmir put into context with millennium-long historical and treering records. Sci. Total Environ., 2020, 722, 137875.

198. Wasson, R. J., Sundriyal, Y. P., Chaudhary, S., Jaiswal, M. K., Morthekai, P., Sati, S. P. and Juyal, N., A 1000-year history of large floods in the Upper Ganga catchment, central Himalaya, India. Quaternary Sci. Rev., 2013, 77, 156-166.

199. Kale, V. S., Singhvi, A. K., Mishra, P. K. and Banerjee, D., Sedimentary records and luminescence chronology of Late Holocene palaeofloods in the Luni River, Thar Desert, Northwest India. Catena, 2000, 40, 337-358.

200. Thayyen, R. J. and Gergan, J. T., Role of glaciers in watershed hydrology: a preliminary study of a Himalayan catchment. Cryosphere, 2010, 4, 115-128.

201. Huss, M. et al., Toward mountains without permanent snow and ice. Earth's Future 5, 2017, 5, 418-435. 
202. Rohrer, M., Salzmann, N., Stoffel, M. and Kulkarni, A. V., Missing (in-situ) snow cover data hampers climate change and runoff studies in the Greater Himalayas. Sci. Total Environ., 2013, 468469: S60-S70; doi: 10.1016/j.scitotenv.2013.09.056.

203. Siderius, C., Biemans, H., Wiltshire, A., Rao, S., Franssen, W. H. P., Kumar, P., Gosain, A. K., van Vliet, M. T. H. and Collins, D. N., Snowmelt contributions to discharge of the Ganges. Sci. Total Environ., 2013, 468, S93-S101.

204. Ouyang, H., Climate changes and water resources management in the HKH region: strategy and implementation. In Paper Presented at ICIMOD-MAIRS joint International Workshop on Climate Change Impacts on Water/Land and Adaptation Strategies in the Tibet-Himalayan Region, Pokhara, Nepal, 27-29 June 2012.

205. Aase, H. A., Chapagain, P. and Tiwari, P. C., Innovation as an expression of adaptive capacity to change in Himalayan farming Mt Res. Dev., 2013, 33(1), 4-10; http://dx.doi.org/10.1659/MRDJournal-D-12-00025.1

206. Tiwari, P. C. and Joshi, B., Environmental changes and sustainable development of water resources in the Himalayan headwaters of India. Int. J. Water Resour. Manage., 2012, 26(4), 883-907; doi:10.1007/s11269-011-9825-y.

207. ICIMOD, Mountains of the World - ecosystem services in a time of global and climate change: seizing opportunities-meeting challenges. Framework paper prepared for the Mountain Initiative of the Government of Nepal by ICIMOD and the Government of Nepal, Ministry of Environment, Nepal, 2010.

208. FAO, Food security in mountains - high time for action. Brochure of the International Mountain Day, Food and Agricultural Organization, Rome, Italy, 2008; http://www.mountaineering. ie/documentbank/uploads/IMD08\%20brochure.pdf

209. Xu, J., Grumbinem R. E., Shrestha, A., Eriksson, M., Yang, X., Wang, Y. U. and Wilkes, A., The melting Himalayas: cascading effects of climate change on water, biodiversity and livelihoods. Conserv. Biol., 2009, 23(3), 520-530.

210. Tiwari, P. C. and Joshi, B., Climate change and rural outmigration in Himalaya. Int. J. Change Adapt. Socio-Ecol. Syst., $2015,2,8-25$.

211. Sharma, G., Partap, U., Dahal, D. R., Sharma, D. P. and Sharma, E., Declining large-cardamom production systems in the Sikkim Himalayas. Climate Change Impacts, Agroeconomic Potential, and Revival Strategies. Mt Res. Dev., 2016, 36(3), 286-298; doi:10.1659/MRD-JOURNAL-D-14-00122.1.

212. Trivedi, A., Disaster-hit Uttarakhand slips out of top ten tourist destinations, Hindustan Times, 29 July 2014; http://www. hindustantimes.com/india/disaster-hit-uttarakhand-slips-out-of-topten-tourist-destinations/story-8NpCXFbLSgfnccrAFXJEpN.html (accessed on 15 June 2017).

213. Press Trust of India, $85 \%$ fall in tourist traffic in Uttarakhand due to floods: ASSOCHAM. The Economic Times, 31 July 2013; $\mathrm{http} / /$ economictimes.indiatimes.com/news/politics-and-nation/85fall-in-tourist-traffic-in-uttarakhand-due-to-floods-assocham/ articleshow/21504671.cms (accessed on 15 June 2017).

214. Schwanghart, W., Worni, R., Huggel, C., Stoffel, M. and Korup, O., Uncertainty in the Himalayan energy-water nexus: Estimating regional exposure to glacial lake outburst floods. Environ. Res. Lett., 2016, 11, 074005; doi:http://dx.doi.org/10.1088/17489326/11/7/074005.
215. Winiger, M. G. H. Y., Gumpert, M. and Yamout, H., Karakorum-Hindukush-western Himalaya: assessing high-altitude water resources. Hydrol. Proc., 2005, 19(12), 2329-2338.

216. Wu, J., Xu, Y. and Gao, X. J., Projected changes in mean and extreme climates over Hindu Kush Himalayan region by 21 CMIP5 models. Adv. Climate Change Res., 2017; https://doi.org/ 10.1016/j.accre.2017.03.001

217. Mishra, V., Climatic uncertainty in Himalayan water towers. $J$. Geophys. Res.: Atmos., 2015, 120(7), 2689-2705.

218. Allen, S. K., Ballesteros-Canovas, J., Randhawa, S. S., Singha, A. K., Huggel, C. and Stoffel, M., Translating the concept of climate risk into an assessment framework to inform adaptation planning: Insights from a pilot study of flood risk in Himachal Pradesh, Northern India. Environ. Sci. Policy, 2018, 87, 1-10; doi:10.1016/2018.05.013.

219. Bolch, T. et al., Status and change of the cryosphere in the extended Hindu Kush Himalaya Region. In The Hindu Kush Himalaya Assessment (eds Wester, P. et al.), Springer Nature, 2019, pp. 209-255; doi:10.1007/978-3-319-92288-1_7.

220. Mool, P. K. et al., Inventory of glaciers and glacial lakes outburst floods (GLOFs) affected by global warming in the mountains of Himalayan region, Indus Basin, Pakistan Himalaya. Pakistan Agricultural Research Council (PARC), ICIMOD, APN, START and UNEP, 2005.

221. Bhagat, R. M., Kalia, V., Sood, C., Mool, P. K. and Bajracharya, S. R., Himachal Pradesh Himalaya, India: inventory of glaciers and glacial lakes and the identification of potential glacial lake outburst floods (GLOFs) affected by global warming in the mountains of Himalayan region. Chaudhary Sarwan Kumar Himachal Pradesh Agricultural University, International Centre for Integrated Mountain Development, Asia-Pacific Network for Global Change Research (APN), Global Change SysTem for Analysis, Research and Training (START) and United Nations Environment Programme (UNEP), 2004.

222. Sah, M., Philip, G., Mool, P. K., Bajracharya, S. R. and Shrestha, B., Uttaranchal Himalaya, India: inventory of glaciers and glacial lakes and the identification of potential glacial lake outburst floods (GLOFs) affected by global warming in the mountains of Himalayan region. Wadia Institute of Himalayan Geology (WIHG), ICIMOD, APN, START and UNEP, 2005.

223. Mool, P. K. and Bajracharya, S. R., Tista Basin, Sikkim Himalaya: inventory of glaciers and glacial lakes and the identification of potential glacial lake outburst floods (GLOFs) affected by global warming in the mountains of Himalayan region. APN, START, UNEP/Regional Resource Centre forAsia and the Pacific (RRC-AP) and ICIMOD, 2003.

ACKNOWLEDGEMENTS. This study has benefitted from collaborations promoted by the Indian Himalayas Climate Adaptation Programme (www.ihcap.in), a project under the Global Programme Climate Change and Environment of the Swiss Agency for Development and Cooperation in cooperation with the Department of Science and Technology, Government of India (GoI), and with support from the Government of Himachal Pradesh and National Mission of Himalayan Studies, Ministry of Environment, Forest and Climate Change, GoI.

doi: $10.18520 / \mathrm{cs} / \mathrm{v} 120 / \mathrm{i} / 774-790$ 